\title{
Manufacturing and assessing new samplers to measure wind soil erosion
}

\author{
Adil Abdelsamia Meselhy* \\ Agricultural Mechanization Unit, Soil and Water Conservation Department - Desert Research \\ Center- Cairo, Egypt \\ Omnia Mohamed Wassif \\ Soil Erosion Unit, Soil and Water Conservation Department - Desert Research Center- Cairo, \\ Egypt \\ *Corresponding author. Email: adil_meselhy@yahoo.com
}

\section{Article Info}

https://doi.org/10.31018/

jans.v13i4.3099

Received: October 17, 2021

Revised: November 28, 2021

Accepted: December 1, 2021

\section{How to Cite}

Meselhy, A. A. and Wassif, O. M. (2021). Manufacturing and assessing new samplers to measure wind soil erosion. Journal of Applied and Natural Science, 13(4), 1390 - 1406. https://doi.org/10.31018/jans.v13i4.3099

\begin{abstract}
Wind soil erosion is one of the most important causes of soil degradation that impede the process of sustainable agricultural development. The first step to mitigating wind erosion hazards is to find an effective and accurate way to assess its severity. Therefore, the main objective of this research was to raise and evaluate the efficiency of the new four traps to measure eroded soil, Fixed Distance trap (FD), Fixed Point trap (FP), Rotary Distance trap (RD) and Rotary Point trap (RP). The study traps RP and FP compared with the Big Spring Number Eight trap (BSNE) (traditional trap) and the traps RD and FD compared with the Bagnold trap (traditional trap). The results indicated that the order of study traps in terms of soil collection efficiency and soil retention efficiency were $\mathrm{RD}>\mathrm{FD}>$ Bagnold $>\mathrm{RP}>\mathrm{FP}>\mathrm{BSNE}$ and $\mathrm{FP}>\mathrm{RP}>\mathrm{RD}>\mathrm{FD}>$ Bagnold $>\mathrm{BSNE}$, respectively. Results proved that the best traps in collecting eroded soil were RP trap followed by FP trap, compared to BSNE trap. Also, the best traps in collecting eroded soil were RD trap, followed by FD trap, compared to the Bagnold trap. The most important results showed that the relative efficiency of RP and FP traps were $181 \%$ and $159 \%$, respectively, compared to BSNE and the relative efficiency of RD and FD traps were $186 \%$ and $172 \%$, respectively, compared to the Bagnold trap. The study proved high accuracy of new traps in measuring soil eroded material, separating soil particles according to their size directly inside traps and determining the direction of the wind compared to traditional traps.
\end{abstract}

Keywords: Distance trap, Horizontal mass flux, Horizontal mass transport, Wind soil erosion

\section{INTRODUCTION}

Wind erosion is a major problem in arid and semiarid regions worldwide that support about one-sixth of the world's population (Skidmore, 2000). Frequent dust storms in these areas not only have a very spectacular character, showing nature's power in moving soil particles. But they also affect the physical characteristics of the atmosphere (Alpert and Ganor, 2001), agricultural systems (Liblik et al., 2003), soil quality (Reynolds et al., 2001), biological systems (Reynolds et al., 2001), building materials (Lefèvre and Ausset, 2002), human activities (Riksen, 2004) and public health (Smith and Lee, 2003, Inyang and Bae, 2006). Wind erosion sorts the most fertile fraction from the soil, lowers its productivity, deposits sediment in ditches and waterways, pollutes the air, reduces visibility, and fouls machinery. Soil erosion is a major land degradation process and affects soil productivity worldwide (Li et al., 2009; García-Ruiz et al., 2015).

It has been estimated that about 75 billion metric tons of soil are removed by wind and water erosion each year and most of these removals take place from agricultural land (Montgomery, 2007). During wind erosion, the soil is moved via three mechanisms known as creep (particles larger than $500 \square \mu \mathrm{m}$ diameter), saltation (particles between 100 and $500 \mu \mathrm{m}$ ), and suspension (particles less than $100 \mu \mathrm{m}$ (Nickling and McKenna Neuman, 2009). The size of the particles carried by the wind decreases exponentially with height ( $\mathrm{Li}$ et al., 2008). The material transported by saltation can affect soils, with a decrease in the thickness of the surface layer, changes in texture, breakdown of structure, and loss of chemical fertility through the decrease of organic matter (OM) and nutrients (Aimar, 2016). Northwestern Coast Zone (NWCZ) is very vulnerable to erosion 
due to its undulating topography and aridity (Fryrear et al., 2008). Passive sediment catchers vary in their design, and all operate by trapping saltation and/or suspension material as airstreams move through the catcher. Catchers have been designed to trap sediment in the airstream within the saltation layer, effectively integrating from the soil surface to about $0.5 \mathrm{~m}$ above the soil (Nickling and McKeena-Neuman, 1997). Most catchers, constructed to sample at discrete heights above the soil surface (Zobeck et al., 2003).

To eliminate the labour and equipment necessary to measure the size distribution of the trapped sediments, Fryrear and Saleh (1993) proposed an alternative methodology to estimate the proportions of saltation and suspension sediment using the horizontal flux of all sediment collected by catchers installed at various heights above the surface (Fryrear, 1986). Measured data have not validated the methodology. Considerable wind erosion data are available from field experiments collected using passive sediment catchers (Zobeck et al., 2003). Typically, point measurements of horizontal sediment flux are collected with catchers placed at heights of about $0.05,0.1,0.2,0.5$ and $1.0 \mathrm{~m}$ above the soil surface. Fitting curves to the horizontal flux measurements and integrating these over heights provides an estimate of the total horizontal sediment discharge at a point in the field. Typically, these data are used to estimate field soil loss (Sharratt et al., 2007; Hagen, 2004). Reliable and direct measurements of sediment flux are not only required for the confirmation and calibration of theoretically derived flux equations (Nickling and McKeena-Neuman, 1997), but are also necessary for assessing the intensity of aeolian processes in each environment (Goossens and Offer, 2000).

Many studies have been devoted to developing and applying a wide variety of instruments used as samplers for the direct measurement of dust. These dust samplers can be classified into two groups: those measuring horizontal dust fluxes, and those measuring vertical dust fluxes. The most important characteristic of a dust sampler is its efficiency. The efficiency of a collector depends on the shape and size of the sampler, the deposition surface inside the sampler, the airflow (wind speed, wind direction, and the sediment's characteristics (Goossens and Offer, 2000). Due to a combination of these factors, the sampler's efficiency varies with the conditions at the time of measurement. BSNE samplers are used in many regions like the USA, Australia, and Egypt to quantify materials transported by saltation and rolling (Goossens et al., 2000). Fryrear (1986) designed big spring number eight (BSNE) sampler. Because it is a passive sampler and requires no power supply, it is cheap and widely used in field experiments. It is the most popular passive sampler in aeolian research Goossens and Buck (2012). Fryrear (1986) BSNE sampler has lower efficiency for particles smaller than 60 microns. It is recommended that this trap be used in coarse grain soils. The sampling efficiency of BSNE decreases with wind speed due to the higher stagnation pressure in the BSNE at higher wind speeds (Goossens et al., 2000).

The stagnation pressure effect is higher for small particles because they have lower inertia and response time to changes in the airflow. Eddies generated in the inlet edge of the sampler cause small particles to be transported outside the sampler. As a consequence of the lower efficiency of BSNE samplers at higher wind speed and smaller particle size and considering that wind speed increases but particle size decreases with height, it can be expected that the amount of material collected by BSNE will also decrease with height. Fryrear et al. (1991) describe a set-up for wind erosion measurements on a circular field with a radius of $50 \mathrm{~m}$. Bagnold sediment trap is among the first ones of vertical slot sampler. It was designed by Bagnold (1943), who was the first instrument for collecting eroded sand in the field. The most important deficiency of this trap was its fixed mouth in the field conditions (Marva and Peterson, 1983). Also, it did not adjust to changes in wind direction. Different kinds of sediment traps have been designed so far and introduced to be used in erosion measuring stations.

Therefore, one of the aims of this study was to assess the four new traps in measuring transmitted sediments from different directions and separation of soil particles size inside traps. Then present the observation data and discuss the calculated measure of soil loss in a direct way (measurement vertical distances along with the trap height) compared with the indirect way (measuring separate vertical points along with the trap height).

\section{MATERIALS AND METHODS}

The evaluation of study traps in the field was carried out in Wadi El-Raml basin. This basin occupies an area of about $144.35 \mathrm{~km}^{2}$ and is located at west of Marsa Matrouh city Northwestern Coastal Zone of Egypt (latitude: between $31^{\circ} 09^{\prime} 20^{\prime \prime}-31^{\circ} 21^{\prime} 58^{\prime \prime} \mathrm{N}$, and longitude: between $\left.27^{\circ} 04^{\prime} 27^{\prime \prime}-27^{\circ} 12^{\prime} 30^{\prime \prime} \mathrm{E}\right)$. The location of the study area is presented in Fig. 1. The soils of Wadi El-Raml are mainly sandy loam in texture. The meteorological data of the study area is mentioned in Table 1 and recorded by National Centers for Environmental Information (NCEI, 2020). The arid Mediterranean climatic conditions of the study area were characterized as short rainy seasons during October-March; about $85 \%$ of the total annual rainfall was recorded between December and February. Analyses of some soil physical and chemical characteristics were carried out according to Klute (1986) and results are given in Tables 2 and 3 . 


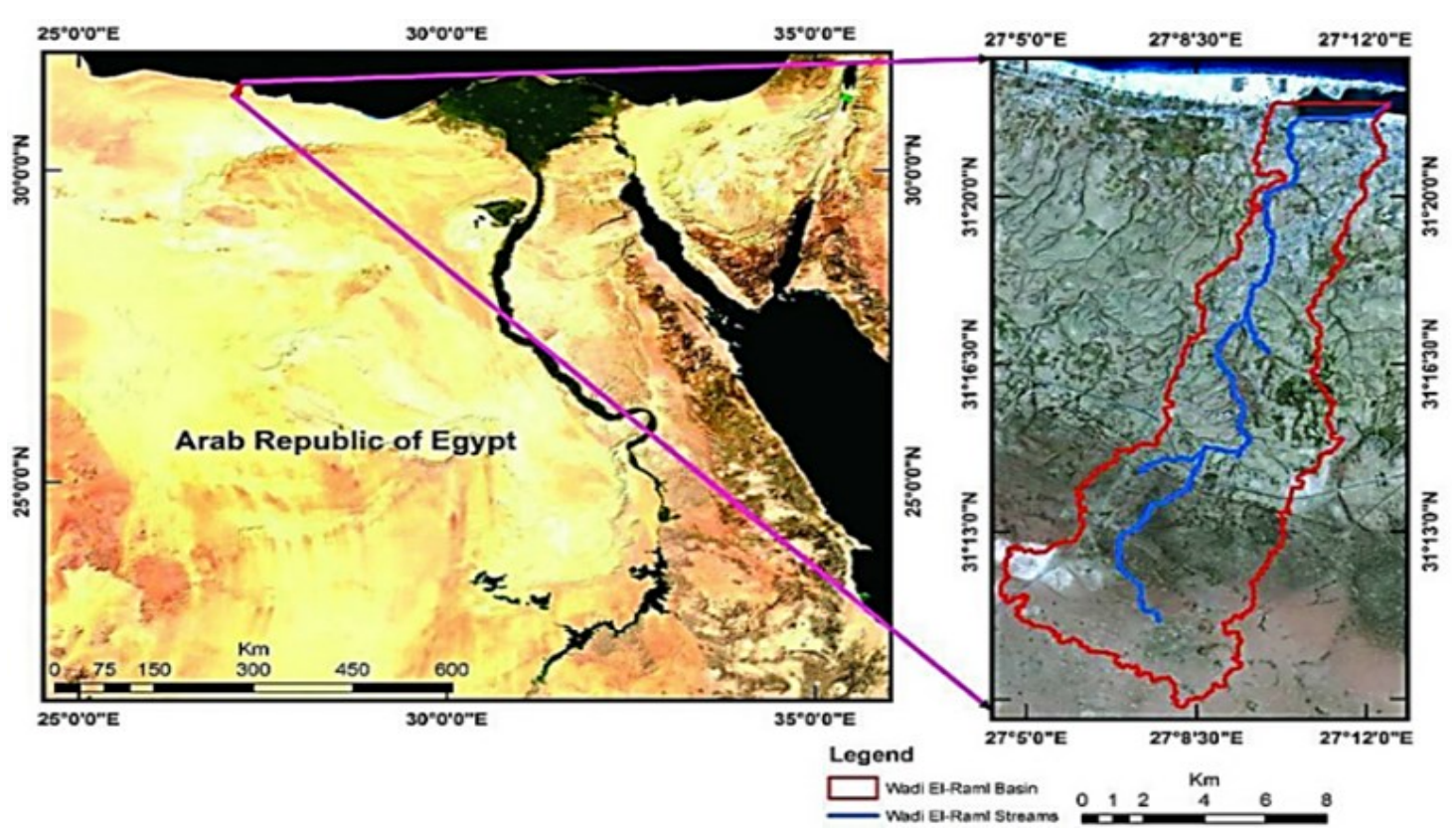

Fig. 1. The location map showing the target study area at NWCZ of Egypt

\section{Design theory of study traps}

The soil particles collection method was the same for all studied traps. The idea of collecting soil particles was based on two opposite vertical openings for the entry and exit of air. There were two vertical sieves between them, the first with a hole size of $0.5 \mathrm{~mm}$ and the second with a hole of $0.1 \mathrm{~mm}$. When the air loaded with soil particles enters from the trap entry hole passes through the two sieves. The sieves obstruct the passage of soil particles and the causes fall into the lower collection basin, divided into three sections. Each section collected a different size of soil particles (creeping

Table 1. Meteorological data of the study area

\begin{tabular}{llllll}
\hline Month & Temperature $\left({ }^{\circ} \mathbf{C}\right)$ & Wind speed $(\mathbf{m} / \mathbf{s})$ & Wind direction & Rainfall $(\mathbf{m m})$ & Moisture $(\%)$ \\
\hline January & 13.10 & 7.62 & NW & 1.86 & 35.84 \\
February & 13.64 & 6.74 & NW & 1.33 & 37.02 \\
March & 14.85 & 7.23 & NW & 2.18 & 35.16 \\
April & 16.85 & 6.78 & NW & 0.04 & 34.44 \\
May & 20.87 & 6.63 & NE & 0.00 & 31.97 \\
June & 23.35 & 6.27 & NW & 0.00 & 31.73 \\
July & 26.22 & 5.77 & NW & 0.00 & 31.77 \\
August & 27.18 & 5.67 & NW & 0.00 & 32.49 \\
September & 26.58 & 5.60 & NE & 0.00 & 33.16 \\
October & 23.95 & 5.49 & $\mathrm{~N}$ & 0.42 & 33.19 \\
November & 18.67 & 5.92 & $\mathrm{NW}$ & 7.20 & 35.70 \\
December & 15.76 & 7.52 & $\mathrm{NW}$ & 0.16 & 37.19 \\
\hline
\end{tabular}

Table 2. Physical and chemical properties of the experimental soil

\begin{tabular}{llllllllll}
\hline $\begin{array}{l}\text { Soil } \\
\text { depth } \\
\text { (cm) }\end{array}$ & $\begin{array}{l}\text { Coarse } \\
\text { sand }\end{array}$ & $\begin{array}{l}\text { Particle size distribution \% } \\
\text { Fine } \\
\text { sand }\end{array}$ & Silt & Clay & $\begin{array}{l}\text { Texture } \\
\text { class }\end{array}$ & $\begin{array}{l}\mathrm{CaCO}_{3} \\
\%\end{array}$ & O.M \% & pH & $\begin{array}{l}\text { EC (ds/ } \\
\text { m) }\end{array}$ \\
\hline $0-20$ & 52.95 & 24.61 & 12.55 & 9.89 & Sandy loam & 6.78 & 0.31 & 7.72 & 1.21 \\
$20-40$ & 48.29 & 24.27 & 17.32 & 10.12 & Sandy loam & 4.6 & 0.35 & 7.65 & 1.18 \\
$40-60$ & 43.41 & 28.17 & 18.14 & 10.28 & Sandy loam & 5.02 & 0.36 & 7.46 & 0.99 \\
\hline \hline
\end{tabular}


Table 3. Particles size distribution and mean weight diameter of soil under consideration

\begin{tabular}{llllllll}
\hline $\begin{array}{l}\text { Range in particles } \\
\text { size, }(\boldsymbol{\mu m})\end{array}$ & $<63$ & $\mathbf{6 3 - 1 0 0}$ & $\mathbf{1 0 0 - 2 5 0}$ & $\mathbf{2 5 0 - 5 0 0}$ & $\mathbf{5 0 0 - 1 0 0 0}$ & $\mathbf{1 0 0 0}$ & MWD ( $10 \mathrm{~m})$ \\
\hline Soil weight, $(\mathrm{g})$ & 12.2 & 17.26 & 13.76 & 18.21 & 17.05 & 21.52 & 560.95 \\
\hline
\end{tabular}

$>0.5 \mathrm{~mm}$, saltation 0.1:0.5 $\mathrm{mm}$ and suspension $<0.1$ $\mathrm{mm}$ ). It is dependent on the trap height; air finally exits from the exit hole of the trap, as shown in (Fig. 2). All studied traps were characterized by:

The ability to separate different soil particles sizes in separate collection basins. So that the study traps had facilitated direct measurement of soil particle size distribution.

Its tight closure, which did not allow rainwater to enter it. Ease of dismantling and installation when taking soil samples from it especially traps RP and RD compared to their difficulty in the case of traps FP and FD.

\section{Specifications of studied traps Rotary points trap (RP)}

This trap type was a rotary reservoir box that rotated with wind direction, as shown in Fig. 3, a-b. This type of trap was one of the types of passive traps collecting the soil particles through the presence of an air inlet hole with dimensions ( $5 \mathrm{~cm}$ height $\times 10 \mathrm{~cm}$ width) which, rotated around a fixed axis by wind vane installed at the end of a horizontal beam to ensure that the trap opening is always in facing the wind direction. This trap worked based on calculated eroded material in an indirect way. Therefore, it was collecting soil particles at points distributed along the vertical distance extending from the soil surface to a height of one meter above the soil surface at distances $(10,32.5,55,77.5$ and 100 $\mathrm{cm}$ ), respectively as shown in Fig. 4 a. Consequently, the soil was collected from each basin of the distributed

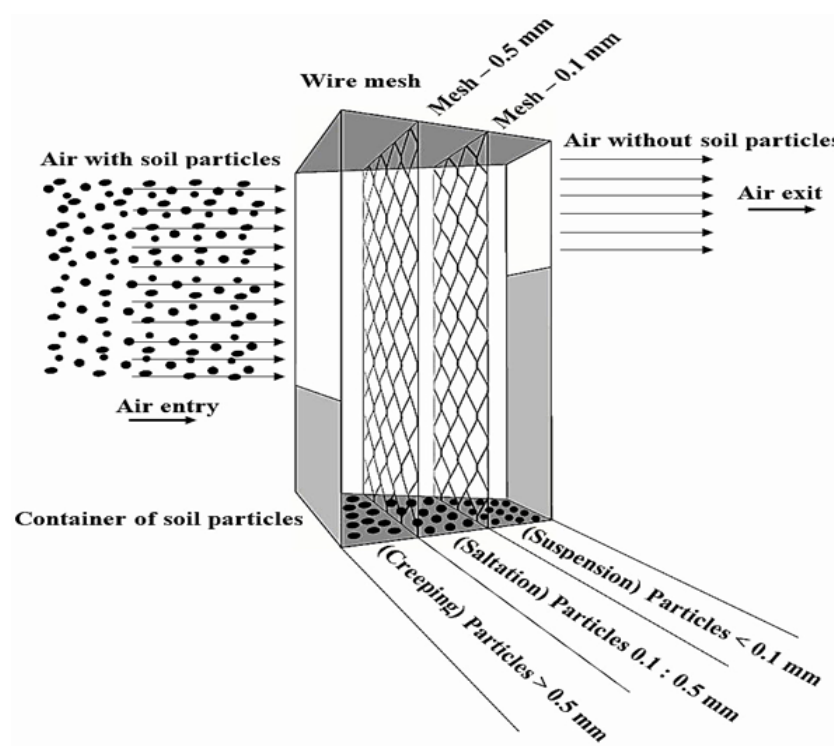

Fig. 2. General idea of collecting soil particles method for the study traps holes along the vertical distance of one meter and then was weighed. After that, a curve was drawn for the relationship between the weight of the soil collected by the trap divided by hole area $\left(\mathrm{g} / \mathrm{cm}^{2}\right)$ on the vertical axis and the horizontal axis placed on it the vertical distances of trap holes from soil surface $(\mathrm{cm})$. Then, the fit equation of the curve was found out, which was integrated to calculate the value of eroded soil $(\mathrm{g} / \mathrm{cm})$ through the distance from 0 to $100 \mathrm{~cm}$.

\section{Rotary distance trap (RD)}

This trap type was a rotary reservoir box that rotated with wind direction as shown in Fig. 6, a-b. This trap had collecting soil particles by having four holes with dimensions (10 cm width $\times 22.5 \mathrm{~cm}$ height). Each hole had an independent collection basin. These four holes were connected to each other along with a vertical distance of one meter. The four holes connected to each other and able to rotate around a fixed vertical axis and rotated by one wing connected to the four holes with a vertical distance of one meter to ensure that the trap opening continued to face the wind, as shown in Fig. 5 a). Therefore, this trap calculated the eroded material by direct way. Therefore, accumulated soil in it, which passed through the hole extending along with the vertical distance one meter, was collected and weighed, so it was the value of the eroded soil.

\section{Fixed points trap (FP)}

This trap type was a fixed reservoir box that not rotate

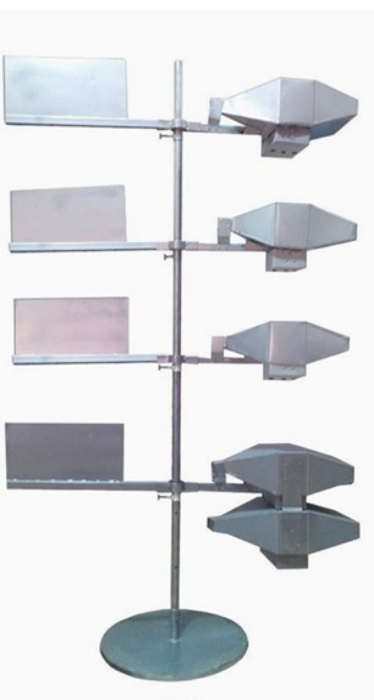

(a)

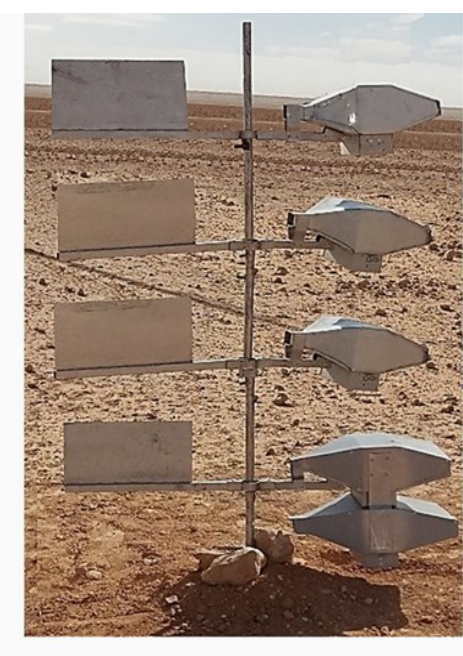

(b)

Fig. 3. Rotary points trap a) photo of trap b) photo of trap in the field 

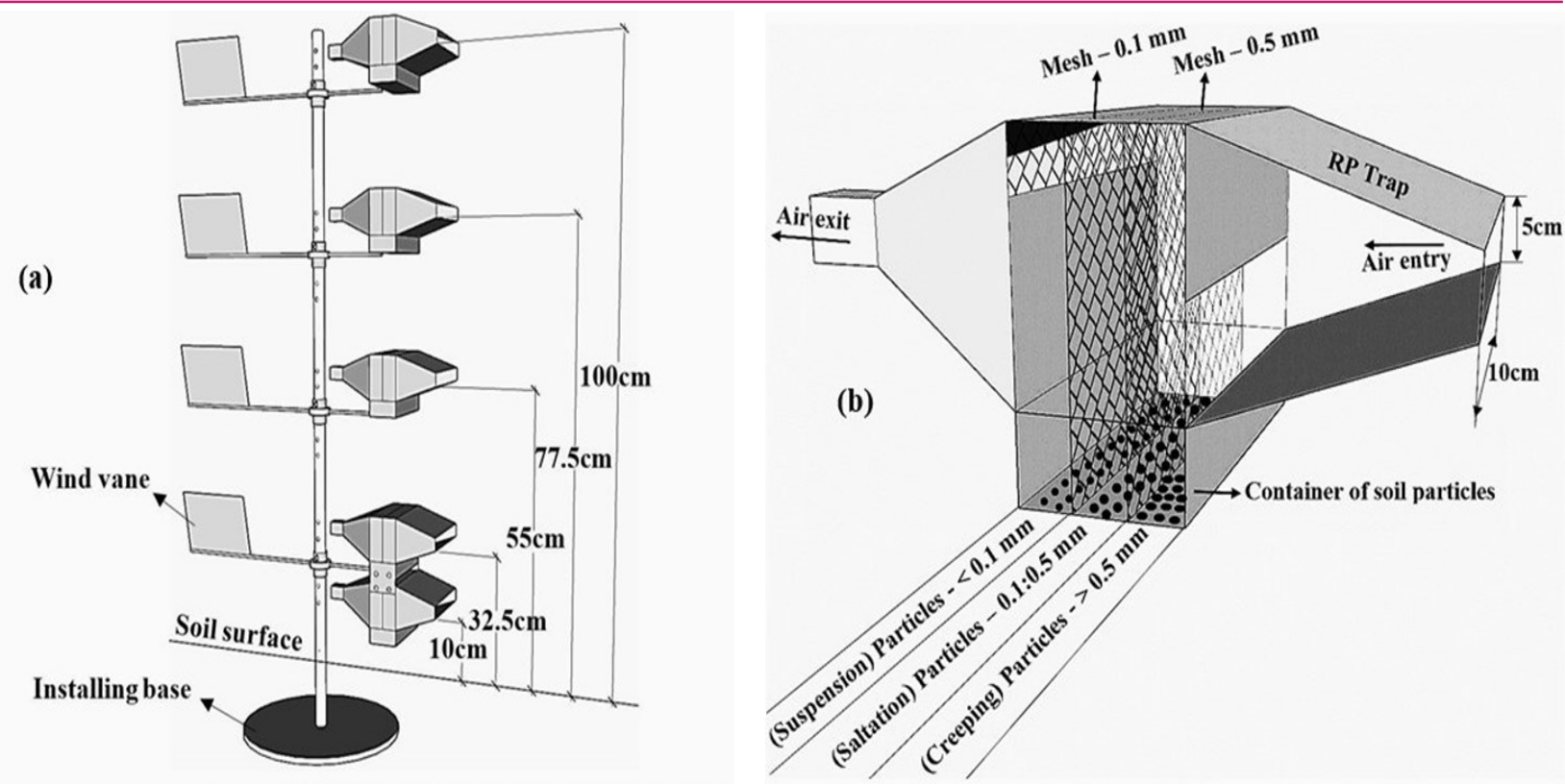

Fig. 4. Rotary points trap a) the scheme of trap with vertical distance of trap opening from soil surface b) the scheme of trap components
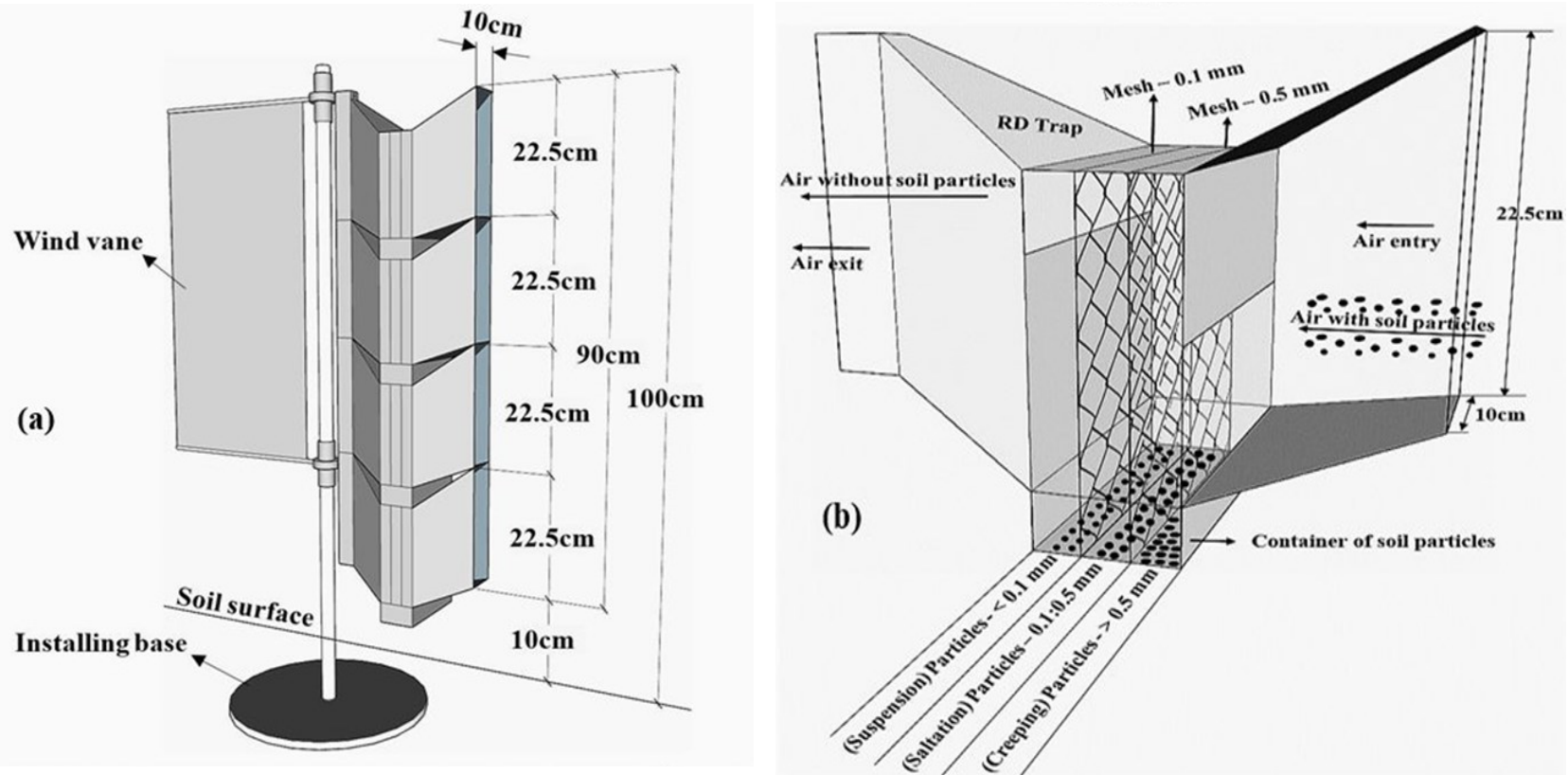

Fig. 5. The scheme of rotary distance trap a) vertical distance of trap opening from soil surface b) single cell components

with the wind direction and calculated eroded material by indirect way. This trap collecting soil particles through separate holes distributed along the vertical plane, extends from the soil surface to a height of one meter, the heights from the soil surface were, $10-32.5$ - 55 - $77.5-100 \mathrm{~cm}$, respectively as shown in Fig. 7, a. At previous heights, a circular tray with eight holes (hole dimensions $5 \mathrm{~cm}$ width $\times 5 \mathrm{~cm}$ height) placed on the tray circumference in the eight geographical directions. Each hole has a collection basin for soil particles, separate from the basins for other holes. This trap consisted of five trays mounted on a vertical shaft. The trays covered with a cover equipped with a wind vane and with a front longitudinal five holes, the dimensions of each one $5 \mathrm{~cm}$ width $\times 5 \mathrm{~cm}$ height for air entry, and in the opposite direction, it had another longitudinal hole of the same dimensions for air exit. This cover was there to ensure that there was no overlap in the accumulation of soil between the holes of the on tray facing the wind, and therefore the soil collected in each hole is specific to one geographical direction only as shown in Fig. 9 and 10. This trap can measure the eroded soil in the eight geographical directions, thus determining the direction of the prevailing wind in the area, which caus- 


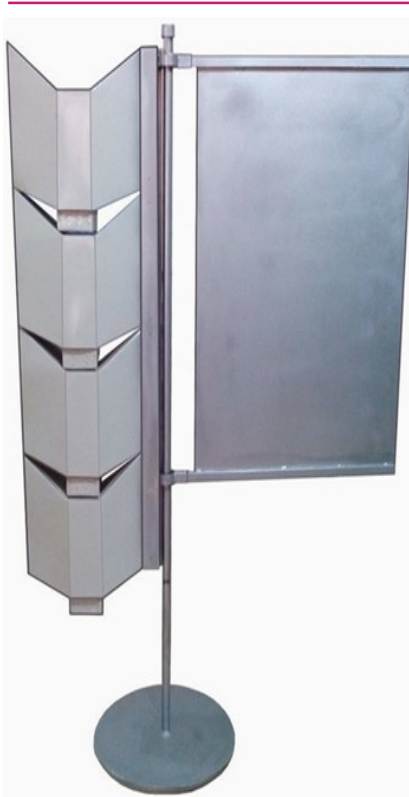

(a)

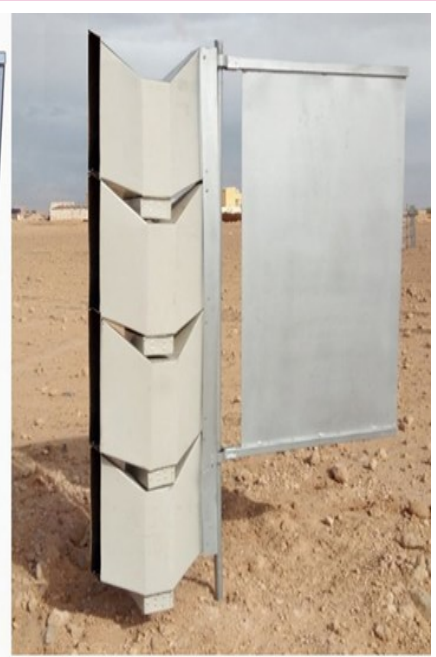

(b)

Fig. 6. Rotary distance trap a) photo of trap b) photo of trap in the field

es soil erosion.

\section{Fixed distance trap (FD)}

This trap type was a fixed reservoir box that did not rotate with the wind direction and calculated eroded material by direct way through collecting soil particles from four vertical holes connected to each other. Each hole is $22.5 \mathrm{~cm}$ in height. It extended along the vertical plane from $10 \mathrm{~cm}$ to a height of one meter. The trap consisted of four circular trays, each tray containing eight holes distributed along the tray circumference in the eight geographical directions. The dimensions of each hole were $5 \mathrm{~cm}$ width $\times 22.5 \mathrm{~cm}$ height. The trays were covered with a cylindrical cover equipped with a wind vane and a front longitudinal opening of dimensions $5 \mathrm{~cm}$ width $\times 90 \mathrm{~cm}$ height for air entry. In the opposite direction, it had another longitudinal opening of the same dimensions for air exit. This cover was there to ensure that there was no overlap in the accumulation of soil between the holes of the one tray facing the wind. Therefore, the soil collected in each hole is specific to one geographical direction only as shown in (Fig. 11, 12 and 13). This trap can measure the eroded soil in the eight geographical directions, thus determining the direction of the prevailing wind in the area, which causes soil erosion. One of the most important disadvantages of this trap is the difficulty of disassembling and installing when taking soil samples and their large size.

\section{Traditional traps}

Big spring number eight trap (BSNE)

The big spring number eight (BSNE) was a traditional

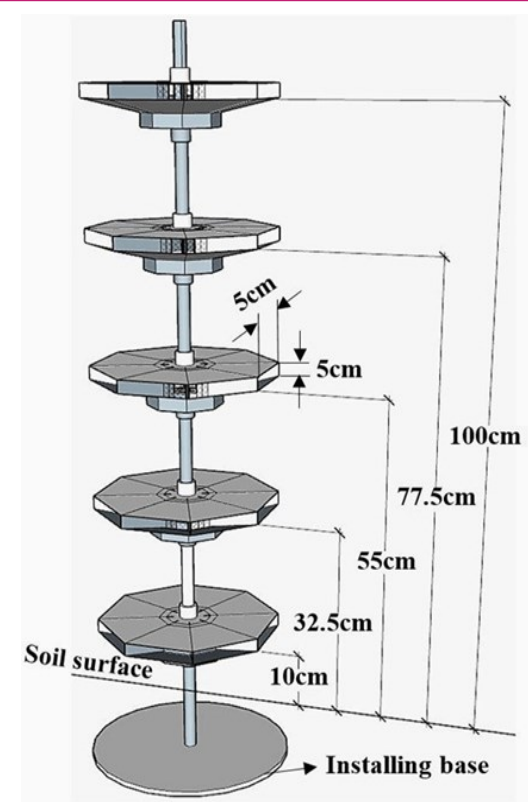

(a)

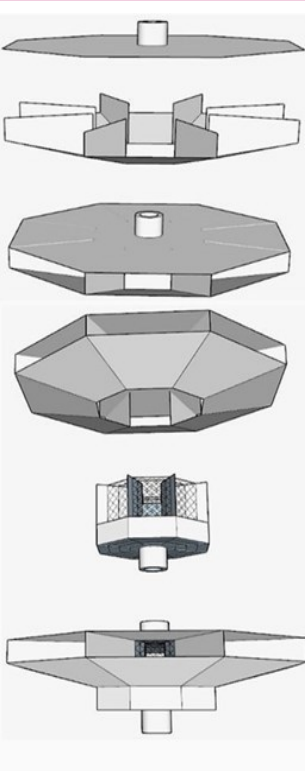

(b)
Fig. 7. Scheme of fixed points trap a) vertical distance of trap opening from soil surface b) tray components

trap for wind erosion measurement indirectly by separate points along the vertical plane by Fryrear (1986). Although it was initially designed to collect airborne dust, it was also frequently used to collect soil and sand. A picture and a diagram are shown in Fig. 14. Dust-laden air passes through a vertical $2 \mathrm{~cm} \times 5 \mathrm{~cm}$ sampler opening. Once inside the sampler, air speed is reduced, and the dust settles in a collection pan. Air discharges through a 60-mesh screen. An 18-mesh screen reduces the movement of the deposited material, preventing the breakdown of the collected sediment and potential loss of very fine particles out of the top of

(a)
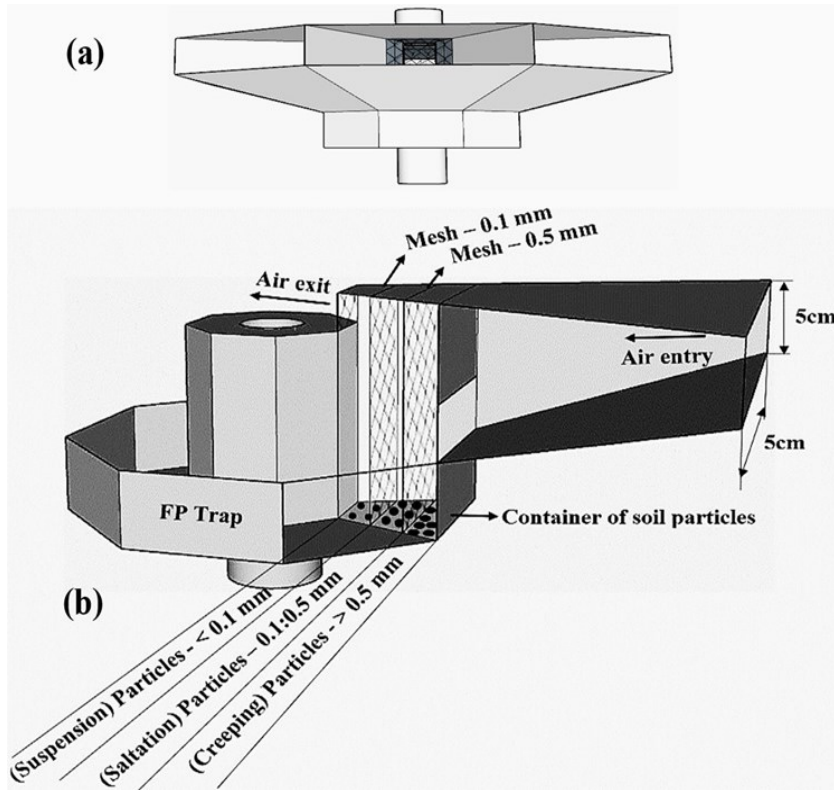

Fig. 8. Scheme of fixed points trap a) the tray b) single-cell components 


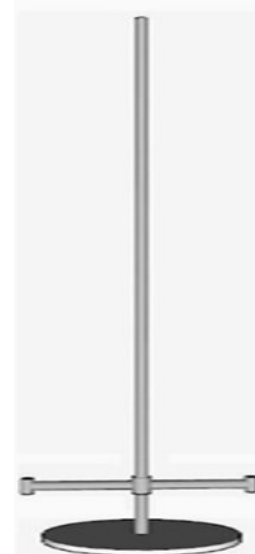

(a)

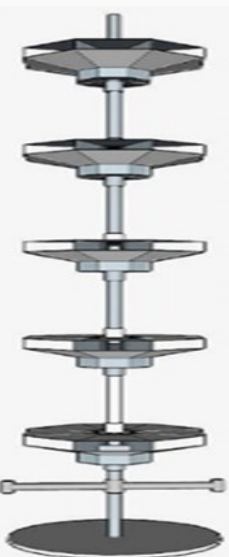

(b)

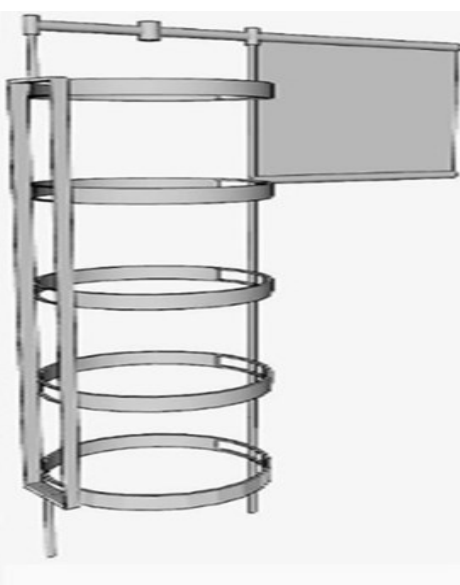

(c)

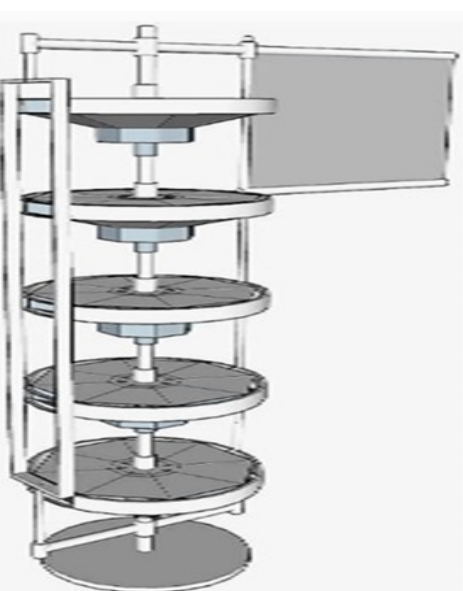

(d)

Fig. 9. Method of install trap cover to prevent reading interference between the tray cells a) vertical shaft b) install the trays on vertical shaft c) cover of preventing reading interference $d$ ) the trap with all components

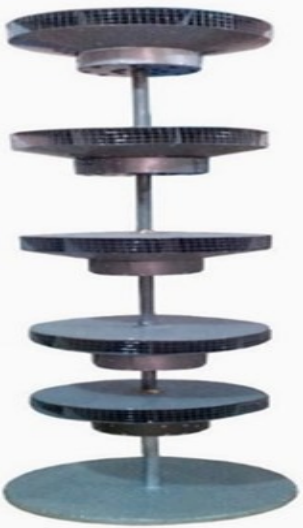

(a)

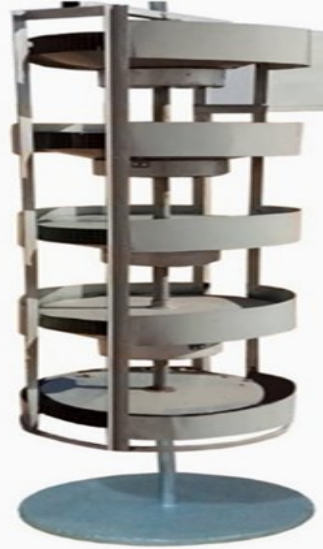

(b)

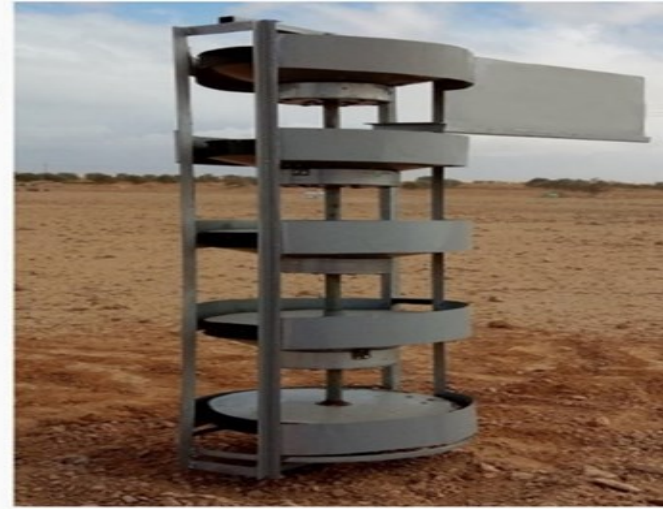

(c)

Fig. 10. Photo of the method of install the trap cover to prevent reading interference between the tray cells a) trap without cover b) trap with cover c) the trap in the field

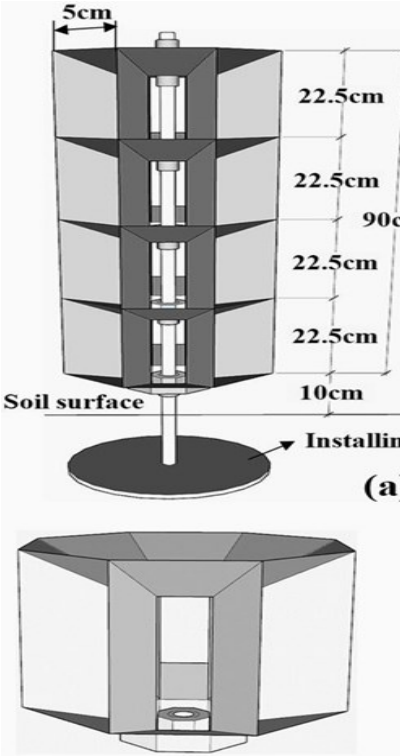

(b)

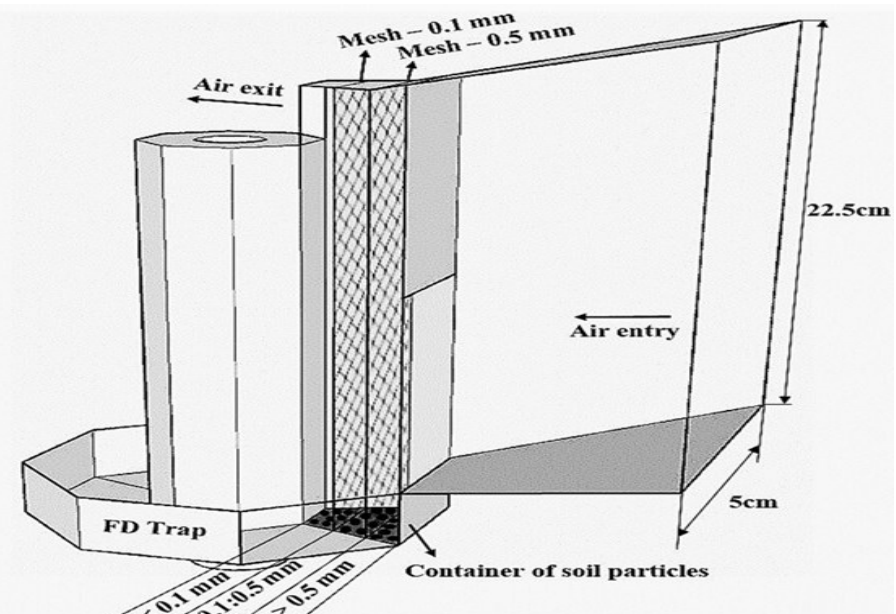

(c)

Fig. 11. Scheme of fixed distance trap a) vertical distance of trap opening from soil surface b) the tray c) single cell components 


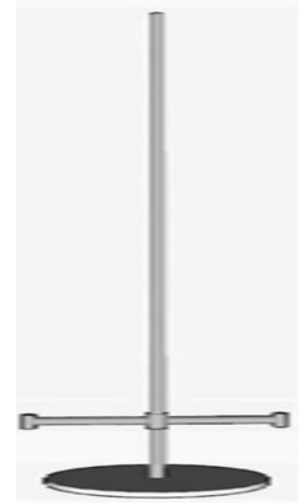

(a)

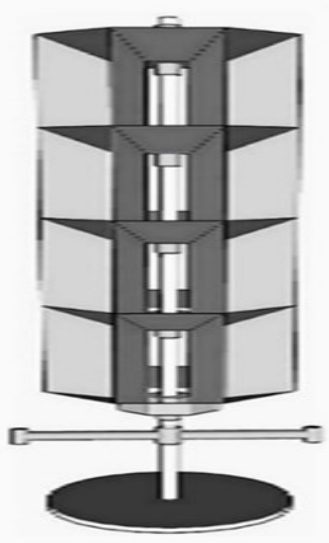

(b)

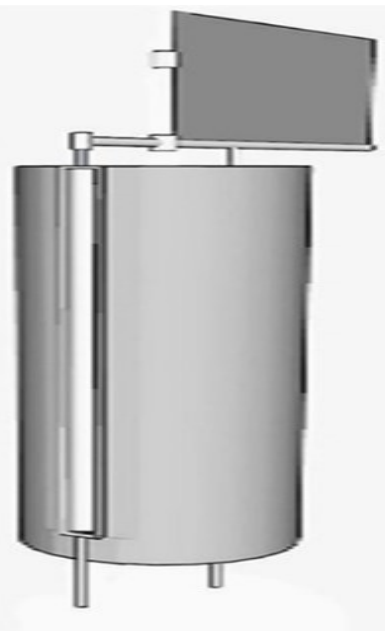

(c)

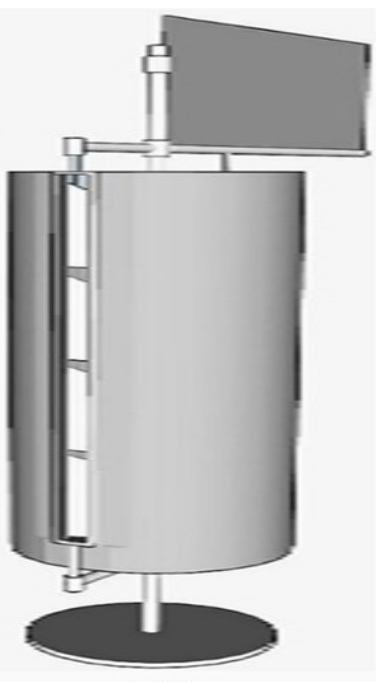

(d)

Fig. 12. Method of install trap cover to prevent reading interference between the tray cells a) vertical shaft b) install the trays on vertical shaft c) cover of prevent reading interference d) the trap with all components

the screen. A wind vane at the rear ensures the sampler was turned to the wind.

\section{The Bagnold trap}

Bagnold was the traditional trap for wind erosion measurement directly by distances along the vertical plane by Bagnold (1943), as shown in Fig. 15. The Bagnold trap was of the type that measures the eroded soil by collecting it in a vertical and longitudinal range and not points so that the accumulated soil directly weighed, and it was the amount of eroded soil. The Bagnold trap was a fixed type

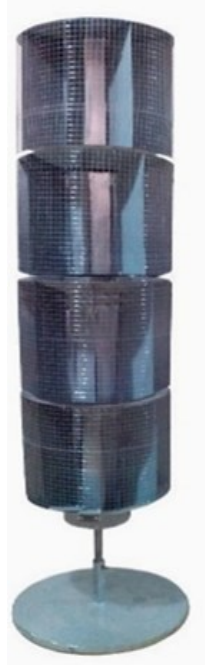

(a)

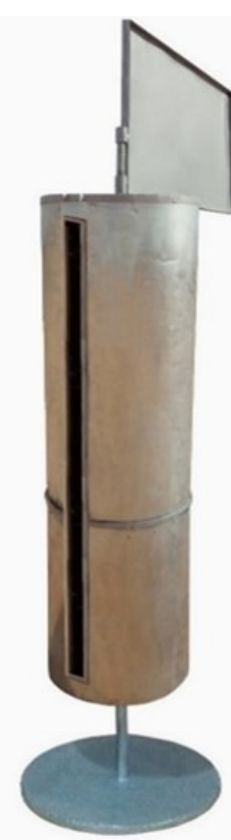

(b)

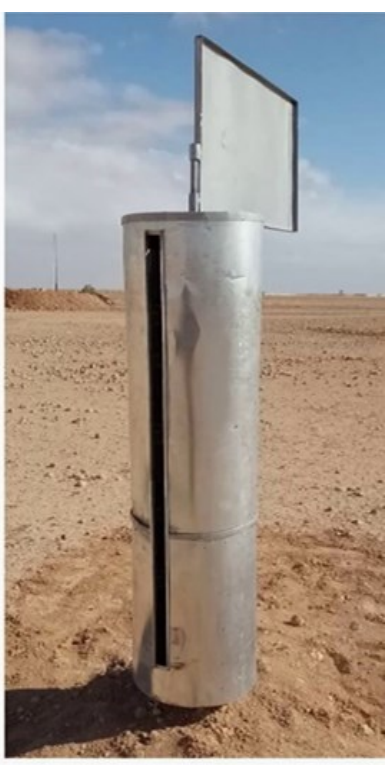

(c)
Fig. 13. Photo of the method of install trap cover to prevent reading interference between the tray cells a) trap without cover b) trap with cover c) the trap in the field. that did not move with the movement of the wind. Thus, the most important disadvantage was that the air intake hole was fixed in only one geographical direction. One of the major defects of this trap was its inability to determine the geographical direction of the wind. But to determine the direction of the wind, more than one of the Bagnold traps must be used, where one trap was placed in each of the geographical directions, which led to a significant increase in costs. This defect was corrected in the design of the proposed study traps, as one trap directly determines the wind direction.
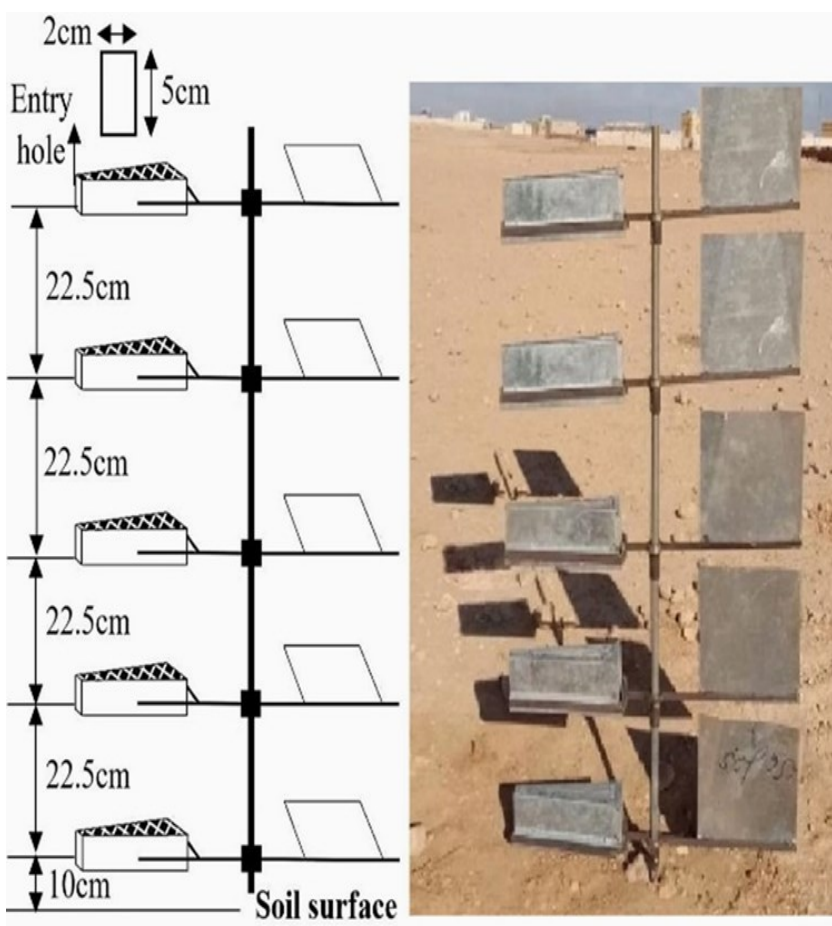

Fig. 14. The big spring number eight trap (BSNE) (Fryrear, 1986) 


\section{Manufacturing costs of study traps}

The traps specially designed for this study were made of 28-gauge galvanized sheet metal, stainless steel 0.5 $\mathrm{mm}$ and $0.1 \mathrm{~mm}$ opening-mesh screen. The cost of manufacturing six study traps FD, FP, RD, RP, Bagnold and BSNE were 91, 82, 71, 60, 53 and 45 \$ US, respectively.

\section{Distribution of traps in the field for the evaluation process}

The traps were spaced $50 \mathrm{~m}$ apart to prevent interference, as shown in (Fig. 16). The traps were placed in the field to evaluate their performance, each trap located in the center of a circle with a radius of $50 \mathrm{~m}$, according to Guerrero et al. (2020). Three replicates were used for each one.

\section{Relative efficiency}

Horizontal mass flux (HMF), defined as the amount of soil passing by unit area of a vertical plane in each individual sampler, was calculated by dividing the amount of material by the sampler's opening area (Funk et al., 2004; Panebianco et al., 2010). This allowed the calculation of HMF for the rotary points trap (RP) is $\left(H M F_{R P}\right)$, Rotary distance trap (RD) is $\left(\mathrm{HMF}_{\mathrm{RD}}\right)$, Fixed points traps $(F P)$ is $\left(\mathrm{HMF}_{\mathrm{FP}}\right)$, Fixed distance trap (FD) is $\left(\mathrm{HMF}_{\mathrm{FD}}\right)$, Bagnold $(\mathrm{BG})$ is $\left(\mathrm{HMF}_{\mathrm{BG}}\right)$ and the $\mathrm{BSNE}$ is $\left(H M F_{B}\right)$. The relative efficiency $(R E, \%)$ of $R P$ and $F P$ relative to $B S N E$ was calculated using Equation 1. However, the relative efficiency (RE, \%) of RD and FD relative to Bagnold was calculated using Equation 2:

$$
\begin{aligned}
& \mathrm{RE}=\frac{\mathrm{HMF}_{\mathrm{X}}}{\mathrm{HMF}_{\mathrm{B}}} \\
& \mathrm{RE}=\frac{\mathrm{HMF}_{\mathrm{Y}}}{\mathrm{HMF}_{\mathrm{BG}}}
\end{aligned}
$$

Where $\mathrm{HMF}_{\mathrm{X}}$ is the horizontal mass flux of the $\mathrm{x}(\mathrm{RP}$, FP) and $y(R D, F D)$ sampler $\left(\mathrm{g} / \mathrm{cm}^{2}\right)$ and $\mathrm{HMF}_{\mathrm{B}}$ is the horizontal mass flux of the BSNE and $\mathrm{HMF}_{\mathrm{BG}}$ is the horizontal mass flux of the Bagnold $\left(\mathrm{g} / \mathrm{cm}^{2}\right)$.

Horizontal mass transport (HMT), defined as the amount of passing soil by unit area of a horizontal plane confined between two definite heights. Calculated for each sampling point by integrating the power, exponential, logarithmic, and linear equations (Equations. 3, 4, 5, and 6, respectively). Which fit an HMF variation as a function of height between 10 and $100 \mathrm{~cm}$ (Funk et al., 2004; Panebianco et al., 2010). The integrations made between 10 and $100 \mathrm{~cm}$ height because slight changes in the lower boundary for the vertical integration may have different effects on the amount of material calculated trough each equation (Funk et al., 2004; Panebianco et al., 2010).

$$
\mathrm{f}(\mathrm{Z})=\sigma \mathrm{e}^{\frac{-\beta}{\mathrm{z}}}
$$

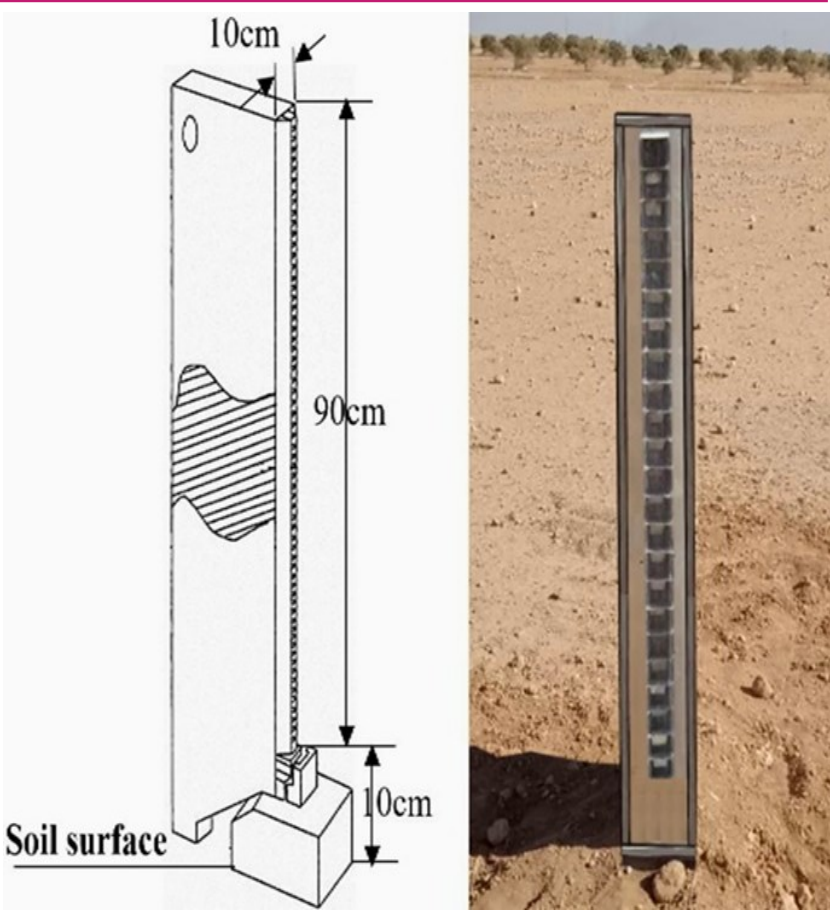

Fig. 15. Bagnold trap (Bagnold, 1943)

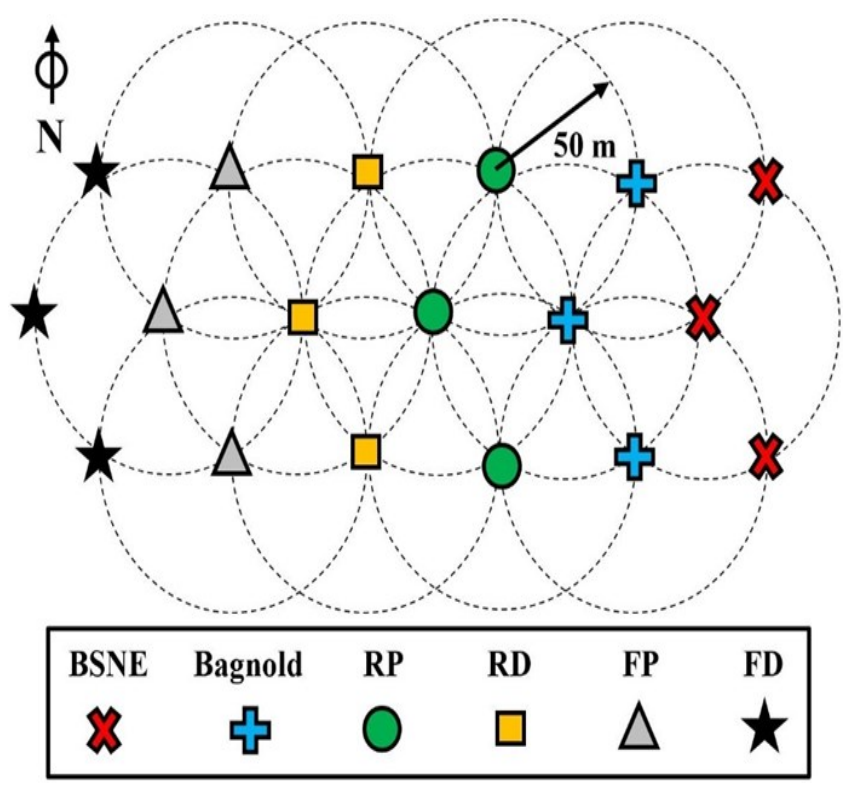

Fig. 16. Study traps distribution in the experimental area

$$
f(Z)=\sigma Z^{-\beta}
$$

$$
\ln f(Z)=f_{0}+\sigma \ln Z
$$

$$
f(Z)=\sigma Z+f_{0}
$$

Eq. 6

Where, $f(z)$ is the horizontal mass flux (HMF), $f_{o}$ is the HMF at the soil surface, $z$ is height, and $\sigma$ and $\beta$ are equation coefficients. The integration of $\mathrm{HMF}_{\mathrm{RP}}, \mathrm{HMF}_{\mathrm{FP}}$ and $\mathrm{HMF}_{\mathrm{B}}$ through each equation allowed the value of HMT of each sampler to be estimated for each equation. The $\mathrm{HMF}_{\mathrm{RP}}, \mathrm{HMF}_{\mathrm{FP}}$ and $\mathrm{HMF}_{\mathrm{B}}$, the HMT of the samplers used, and the equations correlated using the 


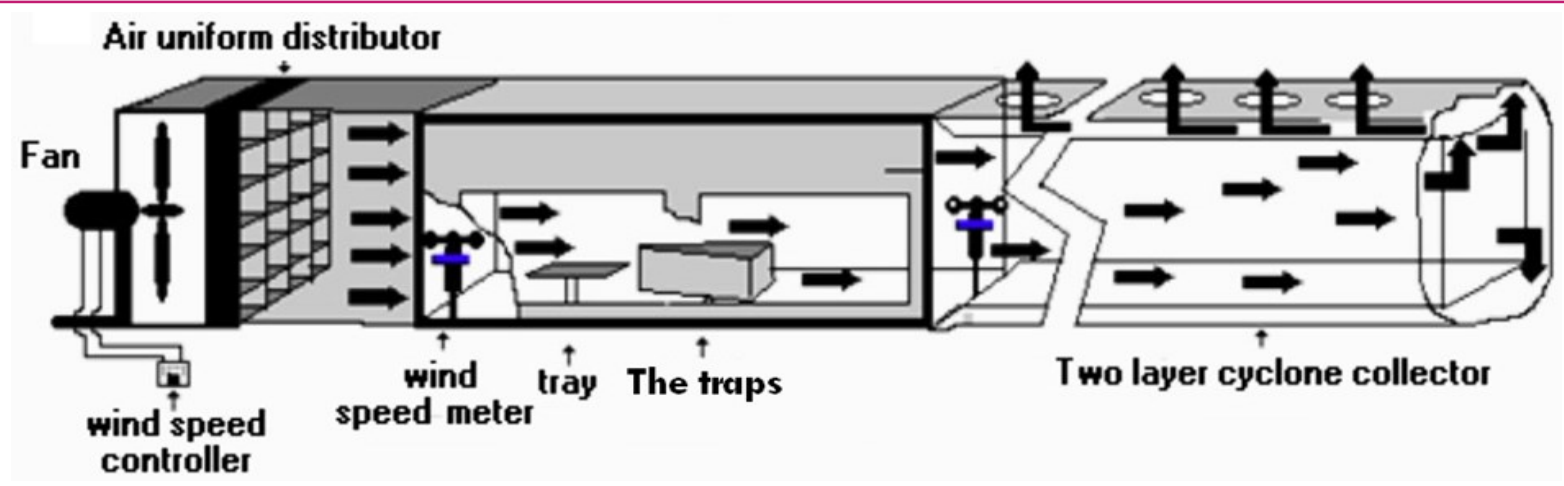

Fig. 17. Test procedure to determine the collection efficiency for traps using wind tunnel

linear regression analysis program of Microsoft Excel.

\section{Collection efficiency}

The collection efficacy calculated after five repetitions of the soil samples from the study area (Wadi El-Raml, Marsa Matruh Governorate) using the wind tunnel at the Desert Research Center, Cairo was shown in Fig. 17. First, the sampler was firmly installed on a base. In front of the sampler was a tray with $290 \mathrm{~mm}$ width, 300 $\mathrm{mm}$ length and $5 \mathrm{~mm}$ height. The height of tray's floor is equal to the average height of sampler's mouth and the distance between tray's edge and sampler's mouth was $50 \mathrm{~mm}$. In each test, we used $650 \mathrm{~g}$ of the soil that had passed the $2 \mathrm{~mm}$ scalp. The soil spread all over the tray by means of a brush and the fan of the tunnel worked each time with a velocity of $7 \mathrm{~m} / \mathrm{s}$ (average wind speed in the field) in the height of $15 \mathrm{~cm}$. The test continued until the soil in the tray was removed. Collection efficiency was calculated using the following formula according to Azimzadeh and Ekhtesasi (2011).

$$
\mathrm{CE}=\frac{\mathrm{M}_{\text {trap }} \mathrm{WD}_{\text {tray }}}{\mathrm{M}_{\text {tray }} \mathrm{WD}_{\text {trap }}}
$$

Where $\left(M_{\text {trap }}\right)$ is the weight of collected soil, $\left(W D_{\text {trap }}\right)$ is the width of trap's mouth, $\left(W D_{\text {tray }}\right)$ is the width of the tray and ( $\left.M_{\text {tray }}\right)$ is the weight of the soil spread on the tray.

\section{Retention efficiency}

Two traps of the same type were placed next to each other in the field and waited until the first storm was hitted on both traps. After that, immediately take the soil collected in both traps and weigh them, so the weight of the dust collected in the first trap was $(A)$ and the weight of the dust collected in the second trap was (B). Leave the first trap empty after taking the accumulated soil from it after the first storm and return the soil after weighing it to the second trap. Waiting until the second storm hits, then directly weigh the soil collected in both traps, where (C) was the weight of soil in the first trap, which emptied after the first storm, and (D) was the weight of soil in the second trap (soil collected from two storms), which left the soil in it after the first storm. Calculate the soil retention efficiency of the traps as shown in (Table 4)

If the value of soil collected in the first trap that emptied after each storm is equal to the weight of the soil collected from the second trap, which soil left in it and taken together after the end of all storms, the soil retention efficiency for traps will be $100 \%$.

\section{RESULTS AND DISCUSSION}

\section{Horizontal mass flux (HMF)}

The fits of the power, exponential, logarithmic, and linear equations to a Horizontal mass flux (HMF, $\mathrm{g} / \mathrm{cm}^{2}$ ) profile to calculate horizontal mass transport (HMT, g/ $\mathrm{cm}$ ) are shown in Fig. 18. Table 5 presents the model parameter coefficients for various equations and their fitting, rather different for each sampler type. The average fitting of the four equations for BSNE, RP and FP, respectively, were in the following order: Power $>$ Exp. $>$ Log. > Linear. The equations investigated fitted better to the $\mathrm{HMF}_{\mathrm{RP}}$ and $\mathrm{HMF}_{\mathrm{FP}}$ than the $\mathrm{HMF}_{\mathrm{B}}$, probably because the potential sampling errors decreased due to the larger opening area of the cyclone collector, especially when the samplers were not correctly orientated to the wind direction. Therefore, the small opening and

Table 4. Soil retention efficiency of the traps

\begin{tabular}{lllll}
\hline Trap & $\begin{array}{l}\text { Soil weight after the } \\
\text { first storm, (g) }\end{array}$ & $\begin{array}{l}\text { Soil weight after the sec- } \\
\text { ond storm, (g) }\end{array}$ & Total weight, (g) & $\begin{array}{l}\text { Soil retention } \\
\text { efficiency, (\%) }\end{array}$ \\
\hline First & A & C & A+C & D \\
Second & B & D & D & A+C $\times 100$ \\
\hline
\end{tabular}

B: weight of the soil left in the second trap from the first storm.

$\mathrm{D}$ : included weight of the soil left in the second trap $(B)$ from the first storm and weight of the soil that collected on it in the second storm. 


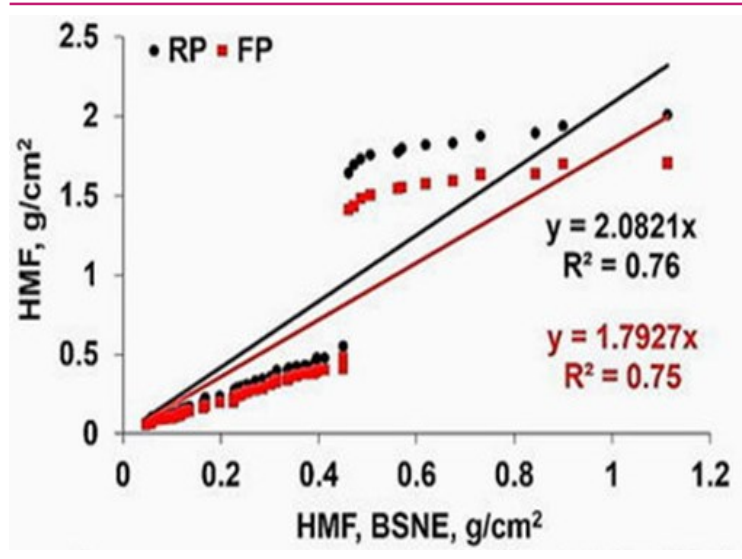

(a)

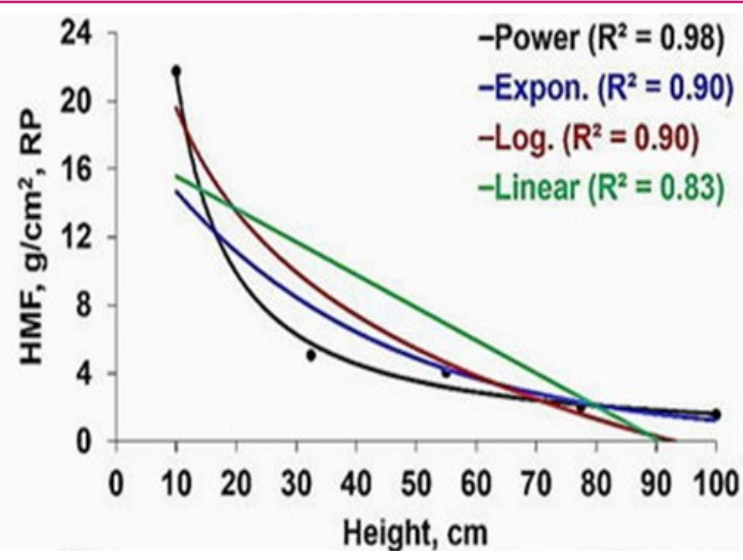

(b)
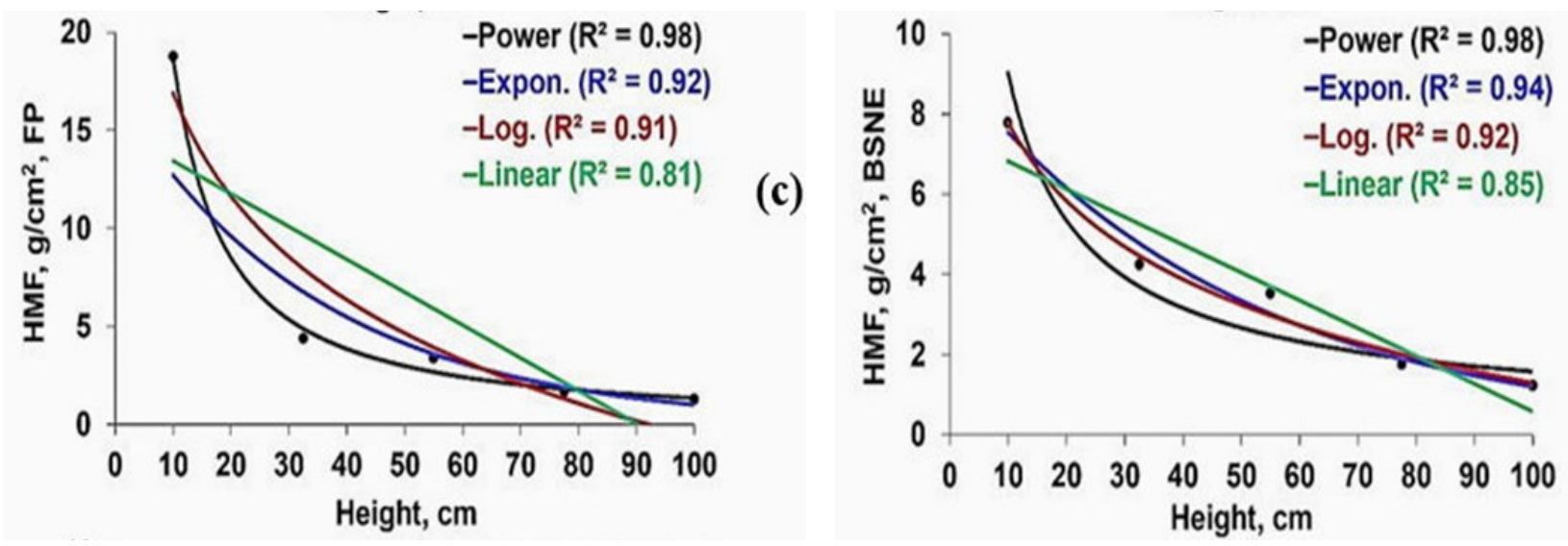

Fig. 18. a) Comparisons of the horizontal mass flux (HMF, $\mathrm{g} / \mathrm{cm}^{2}$ ) obtained with $B S N E$ related to RP and FP traps. Fitting of the power, exponential, logarithmic and linear equations to a horizontal mass flux profiles of b) $R P, c) F P$ and d) BSNE placed at different heights (10, 32.5, 55, 77.5 and $100 \mathrm{~cm}$ from soil surface)

the long tube of the BSNE can complicate the free entrance of the saltation particles, which had an inclination angle concerning the ground (Mendez et al., 2011). The results showed that $\mathrm{HMFRP}$ and $\mathrm{HMF}_{\mathrm{FP}}$, respectively, were 2.08 and 1.79 times higher than $\mathrm{HMF}_{B}$ as shown in Fig. 18a. The results in Fig. 18a showed that there was a significant difference in soil erosion values (ton/ha/y) measured by the measurement method at points along the vertical plane using RP, FP, and BSNE traps, due to the different calculation equations (power

Table 5. Fitting of the power, exponential, logarithmic and linear equations to a horizontal mass flux profiles HMF of BSNE, RP and FP placed at different heights $(10,32.5,55,77.5$ and $100 \mathrm{~cm}$ from soil surface)

\begin{tabular}{|c|c|c|c|c|c|c|}
\hline \multirow{2}{*}{ Equation type } & \multirow{2}{*}{ Formula } & \multirow{2}{*}{ Sampler } & \multicolumn{4}{|c|}{ Parameters } \\
\hline & & & $\sigma$ & $\beta$ & $f_{o}$ & $\mathbf{R}^{2}$ \\
\hline & \multirow{3}{*}{$y=\sigma x^{\beta}$} & BSNE & 51.62 & -0.757 & - & 0.98 \\
\hline \multirow[t]{2}{*}{ Power } & & $\mathrm{RP}$ & 284.16 & -1.12 & - & 0.98 \\
\hline & & FP & 258.48 & -1.14 & - & 0.98 \\
\hline \multirow{3}{*}{ Exponential } & \multirow{3}{*}{$y=\sigma e^{\beta x}$} & BSNE & 9.2458 & -0.02 & - & 0.94 \\
\hline & & $\mathrm{RP}$ & 19.326 & -0.027 & - & 0.90 \\
\hline & & $\mathrm{FP}$ & 16.831 & -0.028 & - & 0.92 \\
\hline \multirow{3}{*}{ Logarithmic } & \multirow{3}{*}{$\mathrm{y}=\sigma \ln (\mathrm{x})+f_{o}$} & BSNE & -2.823 & - & 14.291 & 0.92 \\
\hline & & $\mathrm{RP}$ & -8.787 & - & 39.829 & 0.90 \\
\hline & & $\mathrm{FP}$ & -7.617 & - & 34.459 & 0.91 \\
\hline \multirow{3}{*}{ linear } & \multirow{3}{*}{$y=\sigma x+f_{o}$} & BSNE & -0.0693 & - & 7.5222 & 0.85 \\
\hline & & $\mathrm{RP}$ & -0.1929 & - & 17.493 & 0.83 \\
\hline & & $\mathrm{FP}$ & -0.1673 & - & 15.102 & 0.81 \\
\hline
\end{tabular}


Table 6. Relative, retention and collection efficiencies for study traps

\begin{tabular}{lccc}
\hline Trap type & $\begin{array}{l}\text { Relative Efficiency (RE } \\
\text { \%) under the field meas- } \\
\text { urements }\end{array}$ & $\begin{array}{l}\text { Retention efficiency, (RTE } \\
\% \text { under the field meas- } \\
\text { urements }\end{array}$ & $\begin{array}{l}\text { Collection efficiency (CE } \\
\text { \%) under wind tunnel } \\
\text { measurements }\end{array}$ \\
\hline Fixed point, FP & 159 & 94 & 78 \\
Rotary point, RP & 181 & 90 & 81 \\
Fixed distance, FD & 172 & 86 & 91 \\
Rotary distance, RD & 186 & 88 & 93 \\
Bagnold, BG & - & 83 & 87 \\
BSNE, BS & - & 78 & 73 \\
\hline
\end{tabular}

- exp. - log. - linear). Fig. 19a showed that the best traps in collecting eroded soil by measurement method at points were RP trap followed by FP trap, compared to the traditional trap, BSNE. The results in (Fig. 19b) showed a significant difference between traps RD, FD, and Bagnold, on the other hand the best traps in collecting eroded soil by the measurement method at distances were RD trap, followed by FD trap, compared to the traditional trap Bagnold. Fig. 19b shows that the values of soil erosion measured by the measurement method at distances along the vertical plane were greater than the values measured by the measurement method at points, which indicated that the measurement method at distances was better and more accurate than the measurement method the measurement method at points.

Except for the linear model, all the evaluated equations yielded the highest coefficients of determination and the greatest fit to the data obtained using all the samplers $\left(R^{2}\right.$ values in Table 5 . The power equation yielded the best adjustments to HMF as a function of height. Contrary to our results, Panebianco et al. (2010) and Mendez et al. (2011) maintained that the exponential equation is a very flexible and robust method for estimating the HMT in the sandy loam soils of the semiarid areas.

\section{Horizontal mass transport (HMT)}

The data showed in Fig. 20 presented comparisons of the horizontal mass transport (HMT, $\mathrm{g} / \mathrm{cm}$ ) between all studied traps and each other. The HMT of FD trap 1.63 times higher than HMT of FP trap, HMT of RD trap 1.5 times higher than HMT of RP trap, HMT of RP trap 1.61 times higher than HMT of BSNE trap, HMT of FP trap 1.41 times higher than HMT of BSNE trap, HMT of RD trap 2.79 times higher than HMT of Bagnold trap, and HMT of BSNE trap 1.2 times higher than HMT of Bagnold trap. The results presented in (Fig. 21) showed that comparisons of the horizontal mass transport (HMT, g/cm) obtained with BSNE related to RP and FP traps calculated with different equations (power, exp., log. and linear). As calculated by these Equations, the
HMT of BSNE, RP and FP samplers presented good fitting to each other $(p<0.05)$, depending on the equation used. The HMT of RP (HMT $\mathrm{RP})$ and FP $\left(\mathrm{HMT}_{\mathrm{FP}}\right)$, at equations (power, exp., log. and linear) respectively, were 1.53-1.3, 1.54-1.32, 1.68- 1.43 and 1.79-1.53 times higher than that HMT of BSNE $\left(\mathrm{HMT}_{\mathrm{B}}\right)$ as shown in (Fig. 21, a, b, c, d). This result indicated that wind erosion data obtained with BSNE trap underestimated the real conditions and are lower than those obtained with RP and FP traps. These being similar to the relations among $\mathrm{HMF}_{\mathrm{RP}}, \mathrm{HMF}_{\mathrm{FP}}$ and $\mathrm{HMF}_{\mathrm{B}}$ (Fig. 18, a), this finding is in agreement with the results reported by Mendez et al. (2011), Where he mentioned that the BSNE trap was always lower in its readings as a result of its small entry hole compared to the traps with larger entry holes.

\section{Relative, retention and collection efficiencies for study traps}

In this study, relative efficiency under the field conditions for traps measurements at points (RP and FP) defined as the amount of dust collected by the sampler divided by the amount of dust collected by the BSNE. While relative efficiency for traps measurements at distances (RD and FD) was defined as the amount of dust collected by the sampler divided by the amount of dust collected by the Bagnold. Thus, the relative efficiencies of RP and FP samplers found to be $181 \%$ and $159 \%$ compared to BSNE trap and the relative efficiencies of RD and FD samplers were found to be $186 \%$ and $172 \%$ compared to the Bagnold trap are shown in Table 6 and Fig. 22. The results showed that the order of the study traps in terms of soil retention efficiency under the field measurements were FP > RP > RD > FD > Bagnold $>$ BSNE. The best traps in soil retention efficiency were achieved for traps that had a small entry hole. Despite that, the BSNE trap achieved the lowest retention efficiency. However, it has the lowest entry hole compared to the other study traps due to the absence of a cover for the upper surface of the trap, which exposes it to the entry of rainwater, which causes loss of the collected soil. On the other hand, the order of the study traps in terms of soil collection effi- 

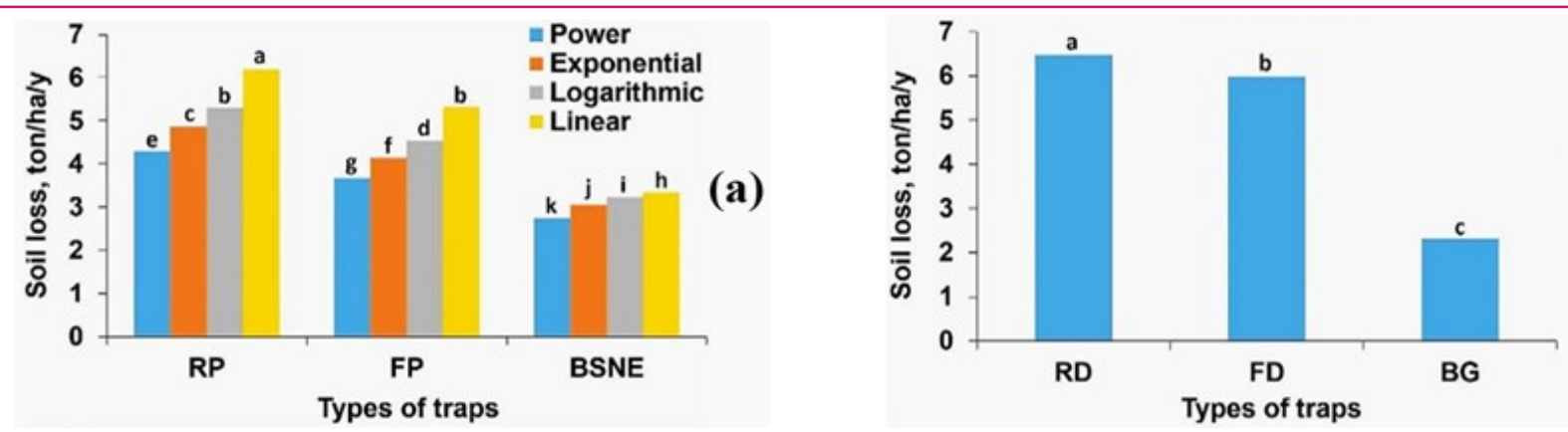

(b)

Fig. 19. a) Soil loss by wind erosion values as calculated using power, exponential, logarithmic and linear equations for traps RP, FP and BSNE. b) Soil erosion values as measured using traps $R D, F D$, and Bagnold (BG). Values followed by different letters are significantly different at $p<0.05$ according to the $L S D$ test, where $L S D$ for RP, FP and BSNE traps at different equations was $=0.05956$, while L.S.D for RD, FD and Bagnold traps was $=0.105926$
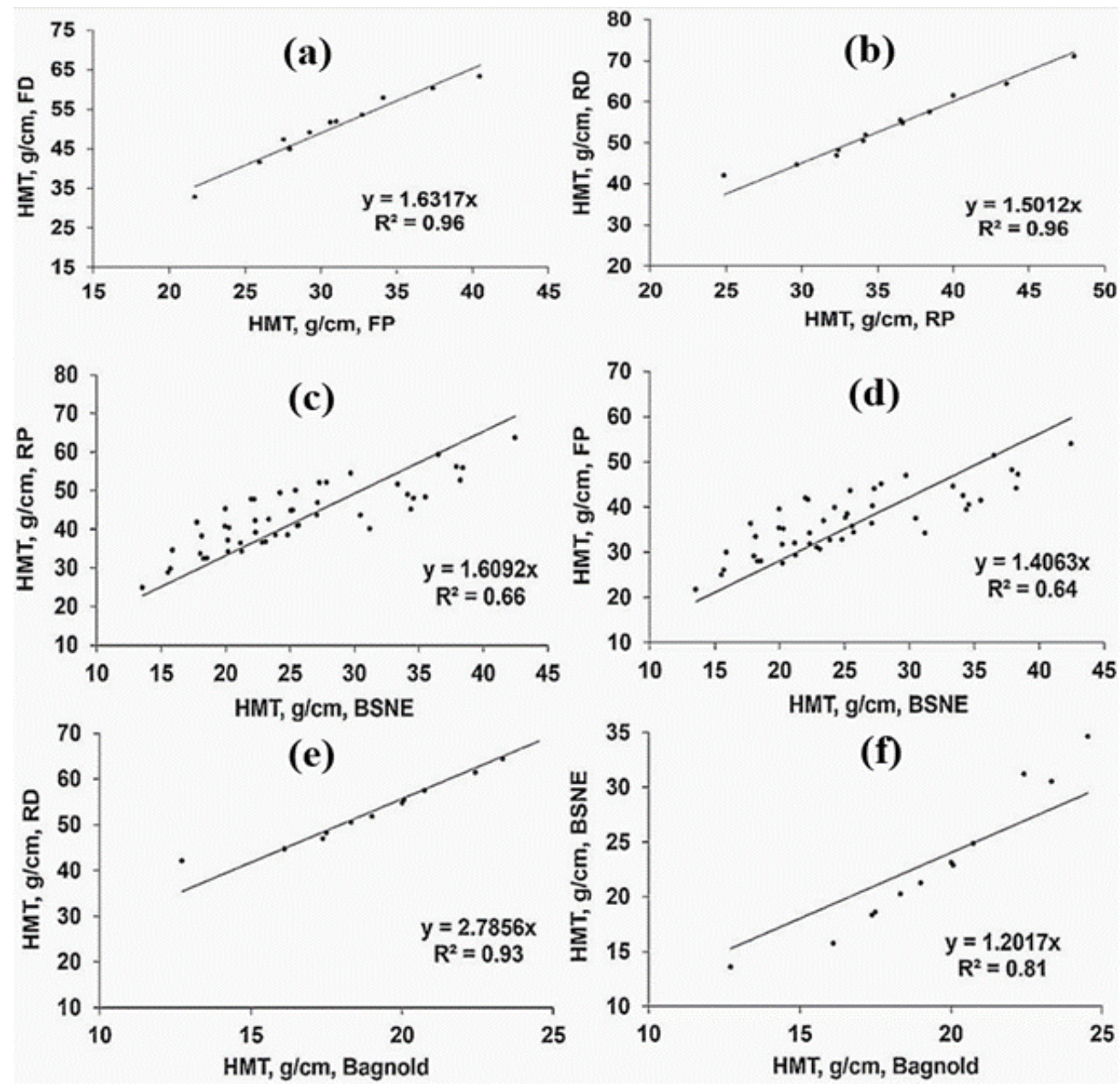

Fig. 20. Comparisons of the horizontal mass transport (HMT, g/cm) between all study traps and each other, a) between $F D$ and $F P, b)$ between $R D$ and $R P, c)$ between $R P$ and BSNE, d) between FP and BSNE, e) between RD and Bagnold, f) between BSNE and Bagnold

ciency was RD > FD > Bagnold > RP > FP > BSNE. The best traps in the soil collection efficiency under wind tunnel measurements achieved for traps with a large entry hole, unlike what happened in the soil retention efficiency. As the entry hole area for the trap was greater, the amount of wind that entered the trap was greater, which caused an increase in soil collected inside it.

\section{Particle size distribution of sediment in different geographical direction}

The study traps FP, FD, RP, and RD characterized by their ability to separate the soil particles which collected inside the trap collector according to their diameter to > $0.5 \mathrm{~mm}$ (creeping), 0.1:0.5 mm (saltation) and $<0.1$ $\mathrm{mm}$ (suspension) compared to the absence of this characteristic in the traditional traps BSNE and $B$ 

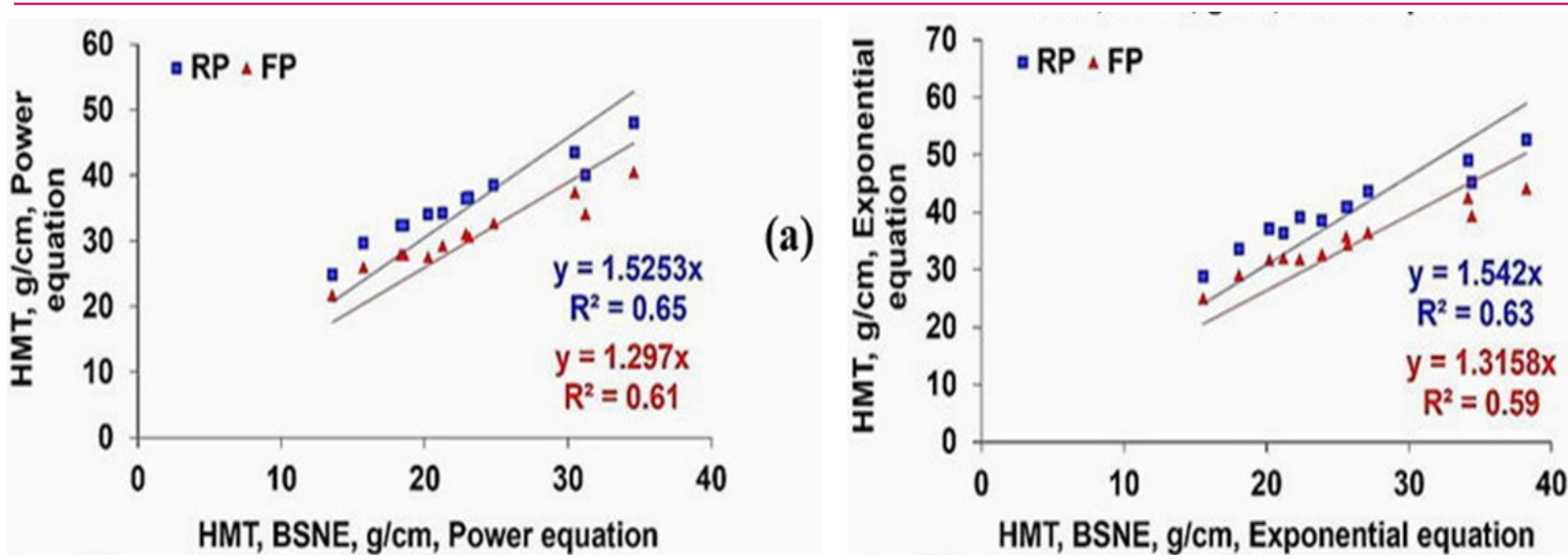

(b)
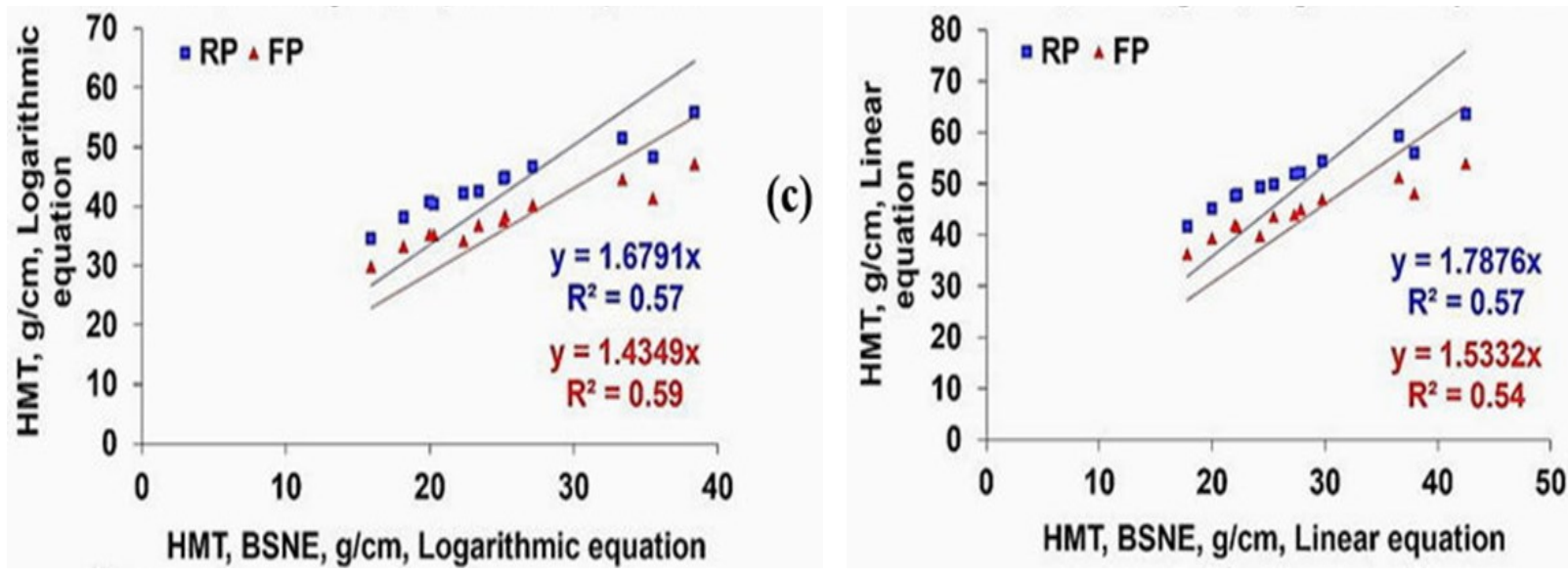

Fig. 21. Comparisons of the horizontal mass transport (HMT, $\mathrm{g} / \mathrm{cm})$ obtained with RP and FP traps related to BSNE trap calculated with different equations a) power, b) exp., c) log. and d) linear.

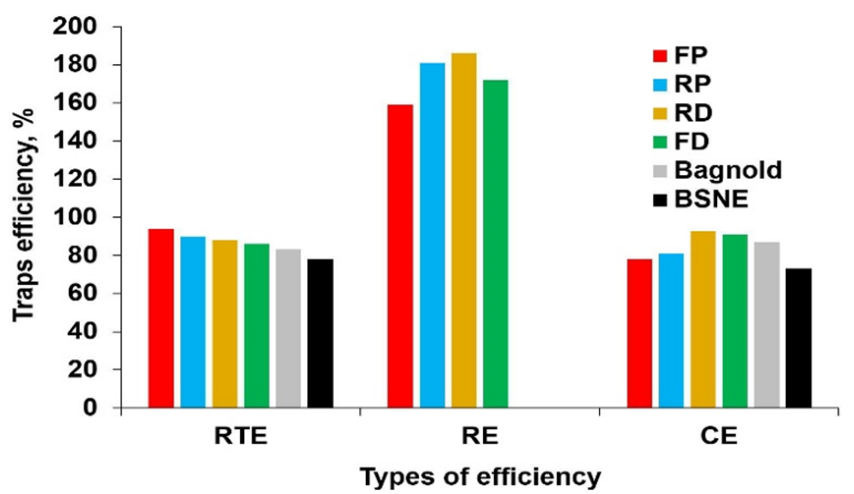

Fig. 22. Relative, retention and collection efficiencies for study traps.

agnold. In these traditional traps, the collected sediment was taken and separated into different particles according to their diameter using sieves in the laboratory. The results presented in (Fig. 23) showed that the order of study traps in collecting the largest weight of creeping, saltation and suspension particles were RD > FD $>$ Bagnold $>$ RP $>$ FP $>$ BSNE. This result can be explained by the area of the trap entry hole. When the area of the trap entry hole is greater, the amount of accumulated soil greater. FD and FP traps and their ability to separate soil particles according to their diam-

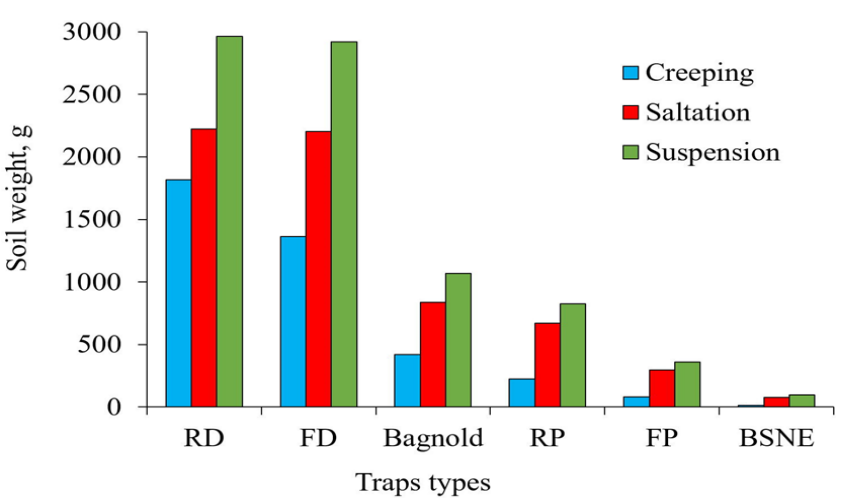

Fig. 23. Particle size distribution of eroded soil.

eters are also characterized by their ability to determine the geographical direction of soil particles accumulation. Thus, the geographical direction of the gustiest winds can be determined, which allows the decision maker to take appropriate methods to protect the soil from wind erosion correctly and appropriately. The results in (Fig. 24, 25 and 26) showed that the windiest geographical direction in the study area was the NW (northwestern) direction. These results agreed by $83 \%$ with the measurements of the wind direction of the meteorological station in the study area as shown in 
Meselhy, A. A. and Wassif, O. M. / J. Appl. \& Nat. Sci. 13(4), 1390 - 1406 (2021)

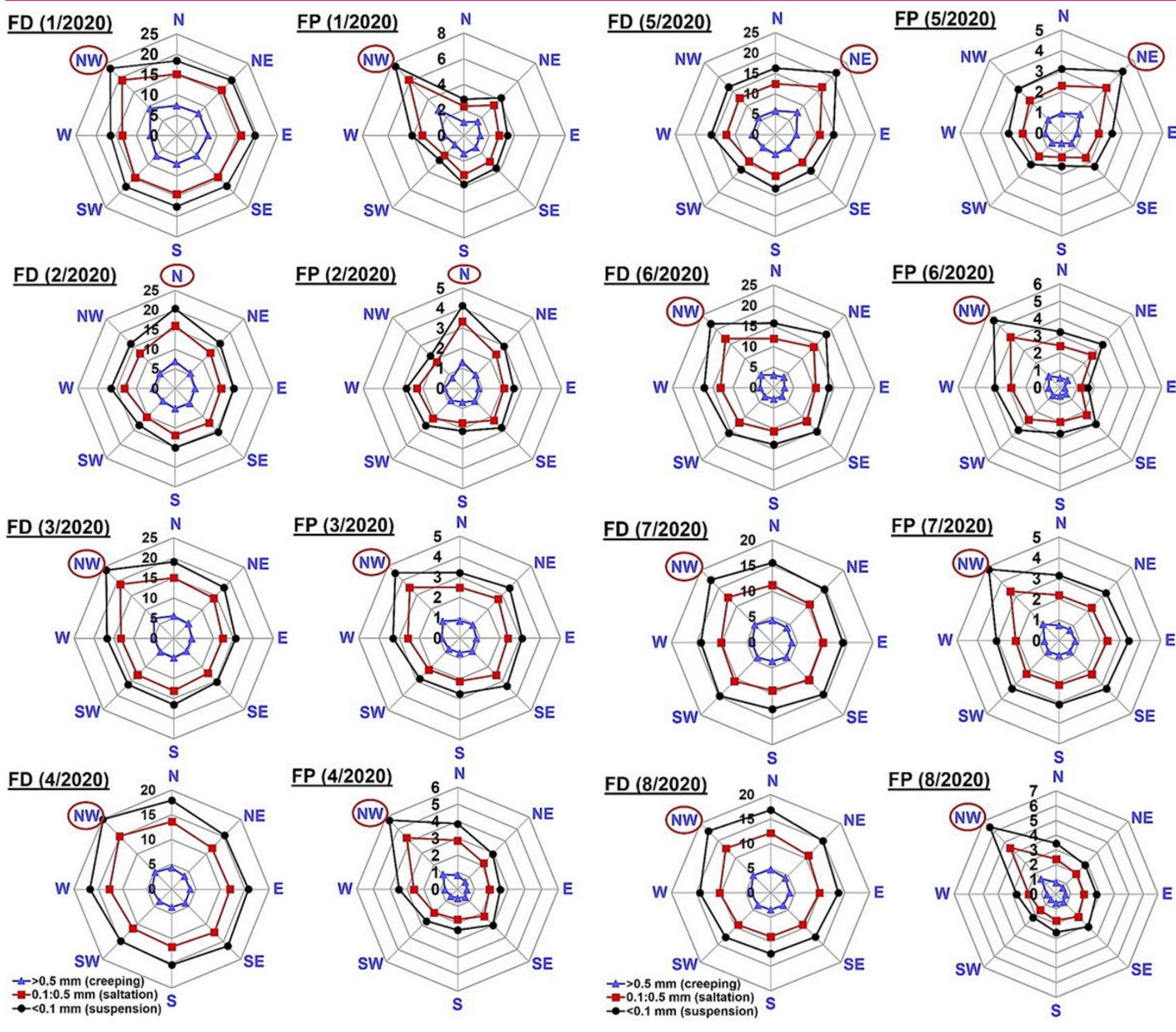

Fig. 24. Particle size distribution of eroded soil $>0.5 \mathrm{~mm}$ as creeping, 0.1: $0.5 \mathrm{~mm}$ as saltation and $<0.1 \mathrm{~mm}$ as suspension) in different geographical direction for FD and FP traps throughout the months 1, 2, 3 and 4 of year.

Table 1.

\section{Correction the reading of traps which measured} soil wind erosion at points

The previous results proved that the method of measuring soil wind erosion at distances is more accurate than the method of measuring at points. Therefore, the values of soil loss by wind erosion measured by the points method, represented by the RP trap, were corrected by comparing them with the values of soil erosion which were measured by the RD trap as shown in Fig. 27, where the correction factors for the wind erosion values which were measured at the points method under study conditions obtained for all types of equations power, exp., log. and linear were 1.5012, 1.334, 1.2249 and 1.0509 , respectively, and the accuracy percentage $\left(R^{2}\right)$

Fig. 25. Particle size distribution of eroded soil $>0.5 \mathrm{~mm}$ as creeping, 0.1: $0.5 \mathrm{~mm}$ as saltation and $<0.1 \mathrm{~mm}$ as suspension) in different geographical direction for FD and FP traps throughout the months 5, 6, 7 and 8 of year.

of the correction factors were $96 \%, 97 \%, 96 \%$, and $93 \%$, respectively.

\section{Conclusion}

The present study comparing the two methods of measuring wind soil erosion indicated that the first method was measured indirectly by measuring at separate points along the vertical plane and the second method was a direct way of measuring at distances along the vertical plane. As well as the comparison between the study traps (FD, RD, FP, and RP) on the one hand and the traditional BSNE and Bagnold traps on the other hand to choose the effective trap for measuring soil erosion, was easy to measure and time-saving in the field. The most important results indicated that 


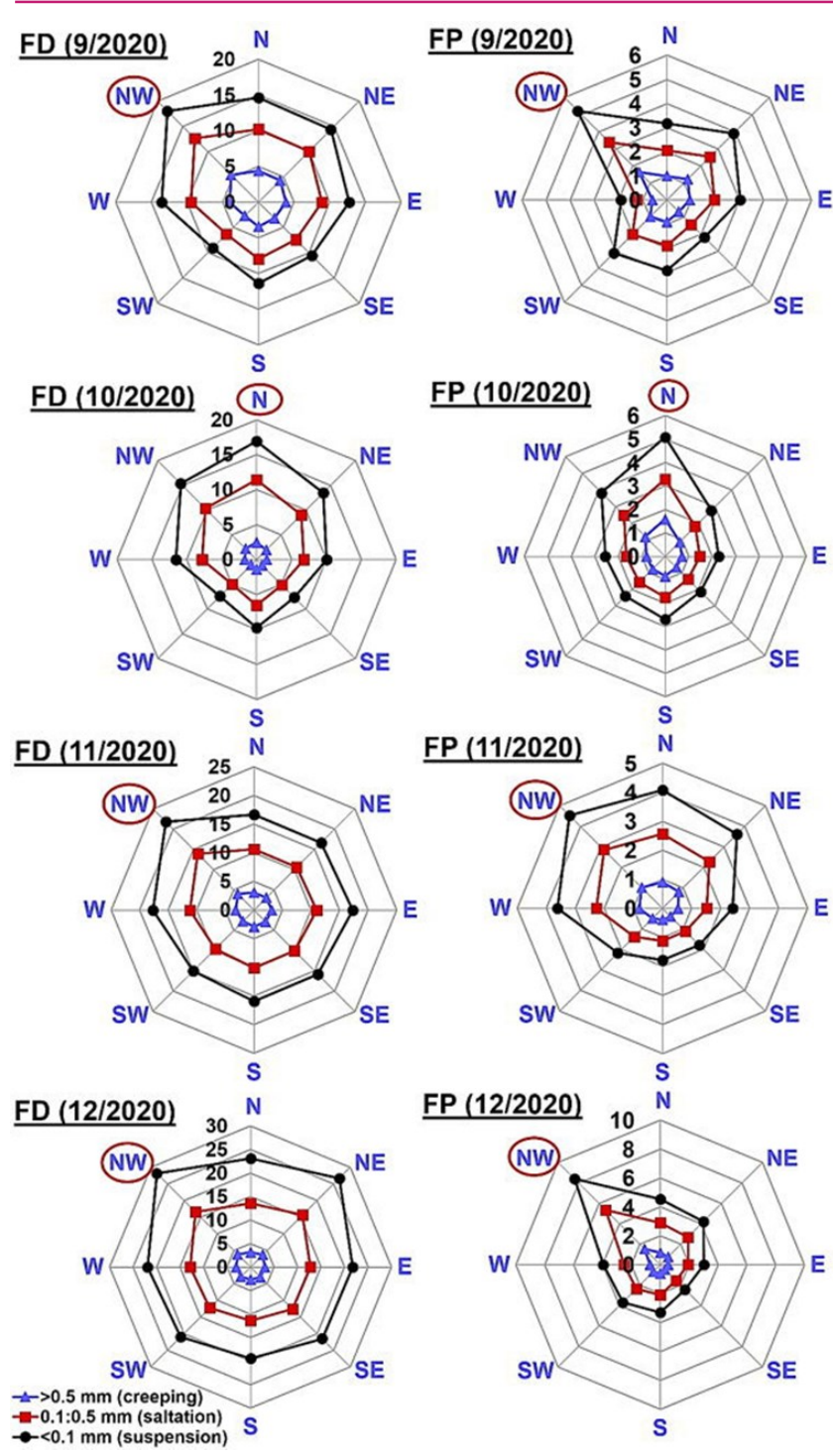

Fig. 26. Particle size distribution of eroded soil $>0.5 \mathrm{~mm}$ as creeping, 0.1: $0.5 \mathrm{~mm}$ as saltation and $<0.1 \mathrm{~mm}$ as suspension) in different geographical direction for FD and FP traps throughout the months 9,10,11 and 12 of year.

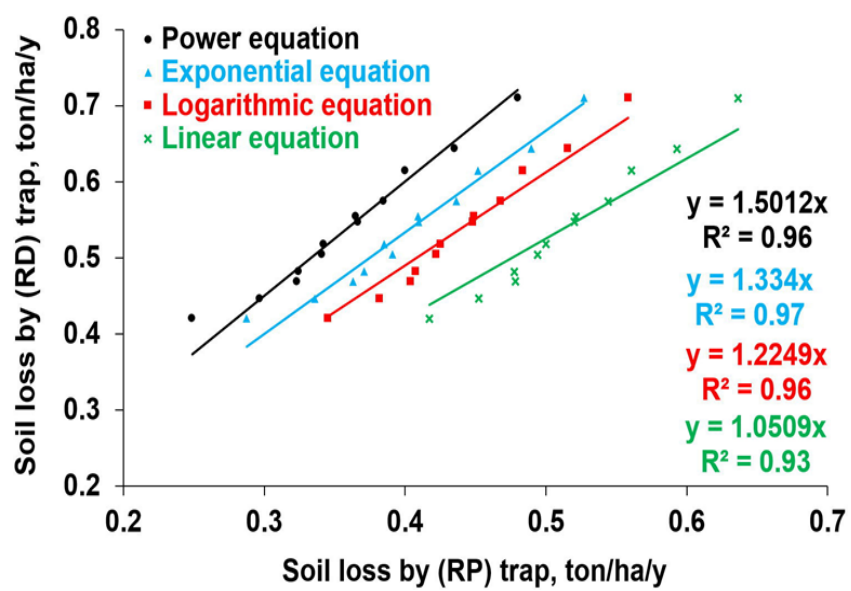

Fig. 27. Comparisons of the soil loss (ton/ha/y) obtained with $R D$ trap related to $R P$ trap at different fitting equations of the power, exponential, logarithmic and linear. the best traps in collecting eroded soil by measurement method at points were RP trap followed by FP trap, compared to the traditional trap, BSNE. The best traps in collecting eroded soil by measurement at distances were RD trap, followed by FD trap, compared to the traditional trap Bagnold. FD and FP traps were characterized by their ability to determine the geographical direction of soil particles accumulation. The windiest geographical direction in the study area was the NW (northwestern) direction.

\section{Recommendations}

From study, it can be recommended that it is necessary to study in detail these traps to evaluate their particle size distribution efficiency and their separation within each reservoir box for each trap, which is better. On the other hand, assessing its accuracy in collecting particle size less than $45 \mu \mathrm{m}$, which cause the most wind erosion hazards on environment and agriculture and then on human health.

\section{Conflict of interest}

The authors declare that they have no conflict of interest.

\section{REFERENCES}

1. Aimar, S. B. (2016). Calidad del material erosionado por el viento en suelos de Argentina. Dr. Sc. Tesis, Universidad Nacional de Córdoba, Argentina, pp. 187.

2. Alpert, P., \& E. Ganor (2001). Sahara mineral dust measurements from TOMS: comparison to surface observations over the Middle East for the extreme dust storm, March 14-17, 1998. Journal of Geophysical Research Atmospheres, 106,; 18275-18286.

3. Azimzadeh, H. R. \& M. R. Ekhtessasi, (2011). A study on Isatis suspension trap efficiency; Advantages and disadvantages DESERT Online at http://jdesert.ut.ac.ir 16:123131.

4. Bagnold, R. A. (1943). Physics of blown sand and desert dunes. New York: William Morrow \& Co.

5. Fryrear D. W., J. E. Stout, L. J. Hagen \& E. D. Vories (1991). Wind erosion: field measurement and analysis. Transactions of the ASAE 34: 155-160.

6. Fryrear, D. W. \& A. Saleh (1993). Field wind erosion: vertical distribution. Soil Sci. 155 (4), 294-300.

7. Fryrear, D. W. (1986) A field dust sampler. Journal of Soil and Water Conservation, 41(2), 117-120.

8. Fryrear, D. W., M. M. Wssif, S. F. Tadrus \& A. A. Ail (2008). Dust measurements in the Egyptian Northwest Zone. Trans. ASABE, 51(4): 1252-1262.

9. Funk, R., E. L. Skidmore \& L. J. Hagen (2004). Comparison of wind erosion measurements in Germany with simulated soil losses by WEPS. Environmental Modelling \& Software, 19; 177-183.

10. García-Ruiz, J. M., S. Beguería, E. Nadal-Romero, J. C. González-Hidalgo, N. Lana-Renault \& Y. Sanjuán (2015). A meta-analysis of soil erosion rates across the world. Geomorphology 239, 160-173. 
11. Goossens, D. \& B. J. Buck (2012). Can BSNE (Big Spring Number Eight) samplers be used to measure PM10, respirable dust, PM2.3 and PM1.0? Aeolian Research, 5, 4349. http://dx.doi.org/10.1016/j.aeolia.2012.03.002

12. Goossens, D. \& Z. Offer (2000). Wind tunnel and field calibration of six Aeolian dust samplers. Atmospheric Environment, 34; 1043-1057.

13. Goossens, D., Z. Offer \& G. London (2000). Wind tunnel and field calibration of five aeolian sand traps. Geomor-

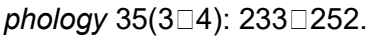

14. Guerrero R., J. L. Valenzuela, J. L. Torres, J. Lozano \& C. Asensio (2020). Soil wind erosion characterization in south-eastern Spain using traditional methods in front of an innovative type of dust collector. International Agrophysics, 34, 503-510.

15. Hagen, L. J. (2004). Evaluation of the Wind Erosion Prediction System (WEPS) erosion submodel on cropland fields. Environ. Softw. Model. 2, 171-176.

16. Inyang, H. I. \& S. Bae (2006). Impacts of dust on environmental systems and human health. Journal of Hazardous Materials, 132; v-vi.

17. Klute, A. (1986). Laboratory measurement of hydraulic conductivity of saturated soil. p. 210-220. In Page, et. El. (eds.). Methods of Soil Analysis, Part I. Physical and Mineralogical Methods, Am. Soc. Agron. Inc. Medison. Wis. USA.

18. Lefèvre, R. A. and P. Ausset, (2002). Atmospheric pollution and building materials: stone and glass. In: Siegesmund, S., Vollbrecht, A., Weiss, T. (Eds.), Natural Stone, Weathering Phenomena, Conservation Strategies and Case Studies: Geological Society Special Publications, vol. 205. pp. 329-345.

19. Li, L., S. Du, L. Wu \& G. Liu (2009). An overview of soil loss tolerance. Catena 78, 93-99.

20. Li, Z. S., D. J. Feng, S. L. Wu, A. G. L. Borthwick \& J. R. $\mathrm{Ni}$ (2008). Grain size and transport characteristics of non $\square$ uniform sand in Aeolian saltation. Geomorphology, 100(3), 484-493. https://doi.org/10.1016/j. geomorph.2008.01.016.

21. Liblik, V., M. Pensa \& A. Rätsep (2003). Air pollution zones and harmful pollution levels of alkaline dust for plants. Water, Air, \& Soil Pollution. Focus, 3; 199- 210.

22. Marva, G. E. \& G. Peterson (1983). Wind erosion sampling in the North Central Region. Paper 83-2133. ASAE, St. Joseph, Mich.

23. Mendez, M. J., R. Funk \& D. E. Buschiazzo (2011). Field wind erosion measurements with Big Spring Number Eight (BSNE) and Modified Wilson and Cook (MWAC) samplers. Journal of Geomorphology, 129; 43-48.

24. Montgomery, D. R. (2007). Soil erosion and agricultural sustainability. PNAS 104, 13268-13272.

25. National Centers for Environmental Information (NCEI) (2020): https://www.ncei.noaa.gov/

26. Nickling W. G. \& C. McKenna Neuman (2009). Aeolian sediment transport. Geomorphology of Desert Environments ed A Parsons and A D Abrahams 517-555

27. Nickling, W. G. \& C. McKenna Neuman (1997). Wind tunnel evaluation of a wedge-shaped aeolian sediment trap. Geomorphology, 18; 333-345.

28. Panebianco, J. E., D. E. Buschiazzo \& T. M. Zobeck (2010). Comparison of different mass transport calculation methods for wind erosion quantification purposes. Earth Surface Processes and Landforms, 35; 1548-1555.

29. Reynolds, R., J. Belnap, M. Reheis, P. Lamothe \& F. Luiszer (2001). Aeolian dust in Colorado Plateau soils: nutrient inputs and recent change in source. Proceedings of the National Academy of Sciences of the United States of America, 98, 7123-7127.

30. Riksen, M., (2004). Off-site effects of wind erosion on agricultural land in Northwestern Europe. In: Goossens, D., Riksen, M. (Eds.), Wind Erosion and Dust Dynamics: Observations, Simulations, Modelling. ESW Publications, Wageningen, pp. 103-121.

31. Sharratt, B., G. Feng \& L. Wendling (2007). Loss of soil and PM10 from agricultural fields associated with high winds on the Columbia Plateau. Earth Surf. Process.Landforms, 32, 621-630.

32. Skidmore, E. L. (2000). Air, soil, and water quality as influenced by wind erosion and strategies for mitigation. In: AGRONENVIRON 2000, Second International Symposium of New Technologies for Environmental Monitoring and AgroApplications Proceedings, Tekirdag, Turkey, pp. 216-221.

33. Smith, J. L. \& K. Lee (2003). Soil as a source of dust and implications for human health. Advances in Agronomy, 80, 1-32.

34. Zobeck, T. M., G. Sterk, R. Funk, J. L. Rajot, J. E Stout \& R. S. van Pelt (2003). Measurement and data analysis methods for field-scale wind erosion studies and model validation. Earth Surf. Process. Landforms, 28, 11631188. 